\title{
Examining Different School Structures' Effect on Reducing the Achievement Gap Between African- American and White Students
}

Eric Reini

Cedarville University

Follow this and additional works at: http://digitalcommons.cedarville.edu/education_theses

\section{Recommended Citation}

Reini, Eric, "Examining Different School Structures' Effect on Reducing the Achievement Gap Between African-American and White Students" (2004). Master of Education Research Theses. 6.

http://digitalcommons.cedarville.edu/education_theses/6 


\title{
EXAMINING DIFFERENT SCHOOL STRUCTURES’ EFFECT ON REDUCING THE ACHIEVEMENT GAP BETWEEN AFRICAN-AMERICAN AND WHITE STUDENTS
}

\begin{abstract}
A thesis submitted in partial fulfillment of the requirements for the degree of

Masters of Education
\end{abstract}

By

\section{ERIC WILLIAM REINI}

B.A. Education, Cedarville University, 1995

2004

Cedarville University 


\section{CEDARVILLE UNIVERSITY}

\section{SCHOOL OF GRADUATE STUDIES}

May 1, 2004

\section{HEREBY RECOMMEND THAT THE
BY Eric William Reini ENTITLED Exam
the Achievement Gap between African-Am
PARTIAL FULFILLMENT OF THE REQ
Education.}

William E. Brown, Ph.D.

President

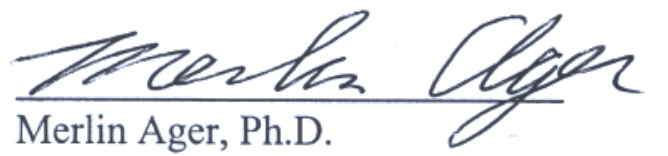

Dean, School of Social Sciences and Professional Studies

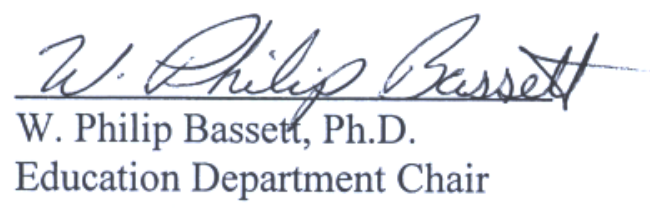

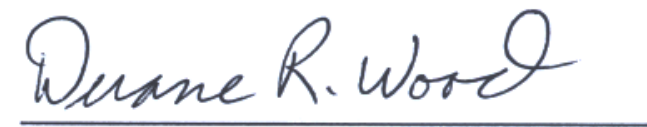

Duane R. Wood, D.B.A.

Academic Vice President

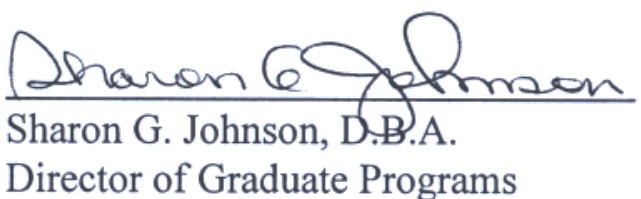

Director of Graduate Programs

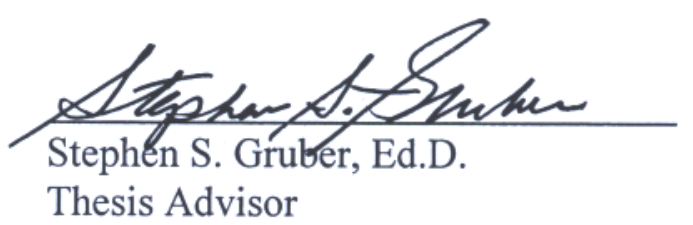




\begin{abstract}
Reini, Eric William. M.Ed. Education Department, Cedarville University, 2004. Examining Different School Structures’ effect on Reducing the Achievement Gap Between African-American and White Students.
\end{abstract}

The fact that an achievement gap between White and African- American students exists is undisputed. The reasons for this gap are many and complex. Evidence does exist, though, that this gap can be narrowed and potentially eliminated. Evidence also exists that demonstrates that when the gap in academic achievement becomes equal African-Americans are more likely to complete college and earn nearly the same income as Whites. Educators must understand the many reasons for the achievement gap and find ways to narrow the gap and further ensure the future success of all students. It is the purpose for this thesis to explore the reasons for the achievement gap and some possible solutions for narrowing the gap. Specifically, the paper will show one possible solution the Academy structure. 


\section{TABLE OF CONTENTS}

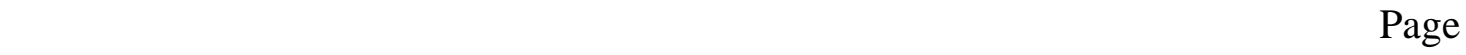

CHAPTER 1: Introduction...................................................

Educational Significance............................................1

Purpose...................................................................

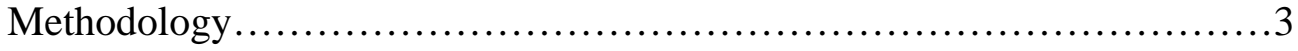

Biblical Integration................................................4

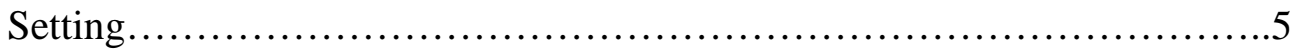

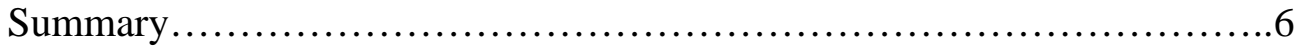

CHAPTER 2: Review of Literature.........................................

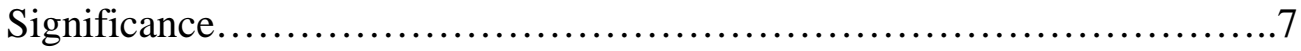

Statistics Regarding the Existence of an Achievement Gap..................7

Achievement Gap Statistics for Ohio Schools.........................8

Analysis of the Statistics............................................12

What Students Think about the Achievement Gap..........................16

Identifying the Causes for the Gap.....................................17

Some Solutions for the Gap........................................19

Comprehensive School Reform....................................22

Talent Development Model..............................................24

Career Academy Programs........................................... 25

Twilight School....................................................29

Outcomes of Career Academies..........................................30

Possible Reasons Why Career Academies Promote Higher Achievement......31

CHAPTER 3: The Effectiveness of Career Academies.............................32 
Introduction .32

Columbus Pathways to Success Initiative (CPSI) ........................... 32

High Schools That Work (HSTW) .................................... 33

The Talent Development Model...........................................35

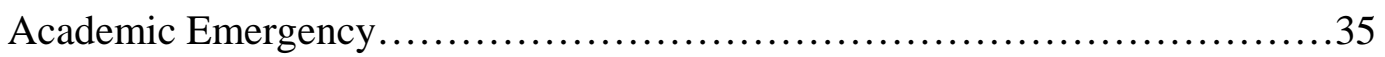

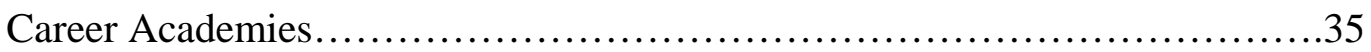

Architecture, Construction, and Engineering Academy........................36

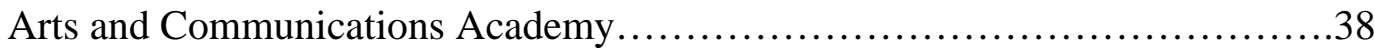

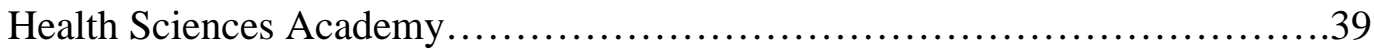

Technology, Engineering, and Manufacturing Academy......................40

Freshman Success Academy..............................................41

Teacher Buy-In...................................................41

Lead Teachers........................................................41

Teacher Collaboration....................................................42

Small Learning Communities..........................................43

Career Connections......................................................43

Communication with Parents.........................................43

The Importance of Academic Achievement.................................44

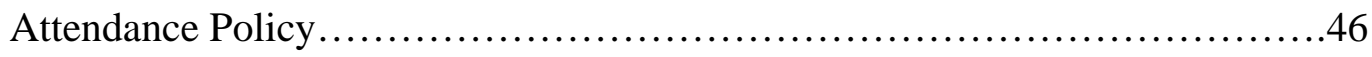

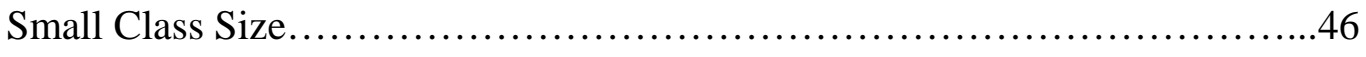

Acceleration Academy..............................................46

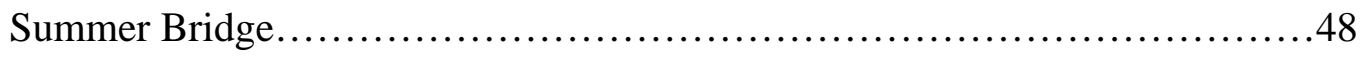

Ohio Ninth Grade Proficiency Tests...................................48 
Rewards and Motivation...........................................49

Awards Assemblies........................................................50

Honor Roll Students................................................... 51

Hand Prints...........................................................51

Cleveland Trip.......................................................52

Team T-shirts...................................................52

Pilgrim Mentoring..................................................53

The Research Process...............................................53

Results within the School...............................................54

Ohio Ninth Grade Proficiency Test Results.............................55

Failure Rates.......................................................56

Statistics Comparing EHS with Ohio by Race.............................57

Attendance Rates by Race..........................................5 57

Proficiency Test Results by Race....................................58

Significance of the Results........................................60

CHAPTER 4: Perspectives, Conclusions, and Recommendations.................61

Perspectives and Conclusions of Teachers..............................61

Perspectives and Conclusions of School Administrators...................64

Perspectives and Conclusions of Students..............................67

Perspectives and Conclusions of Parents...............................69

Perspectives and Conclusions of Researchers............................71 
APPENDICES................................................................... 74

APPENDIX A: Common Syllabus.........................................74

APPENDIX B: Student Credit Check.....................................77

APPENDIX C: Team Meetings...........................................79

APPENDIX D: Phone Calls and Parental Involvement......................80

APPENDIX E: Data Collection............................................

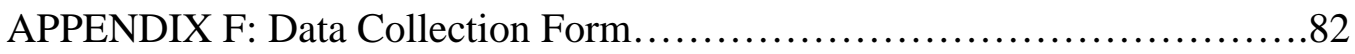

APPENDIX G: Ticket Incentive.......................................... 83

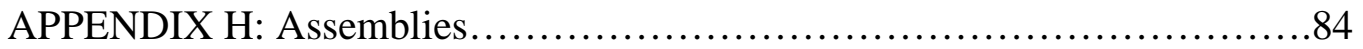

APPENDIX I: Follow Me to Honor Roll Certificate...........................85

APPENDIX J: Phone Log Sheet..........................................86

APPENDIX K: Freshman Academy Student Success Contract..................87

APPENDIX L: Teacher Questionnaire..................................... 88

APPENDIX M: School Administrator Questionnaire..........................89

APPENDIX N: Parent Questionnaire.....................................90

APPENDIX O: Student Questionnaire.....................................91

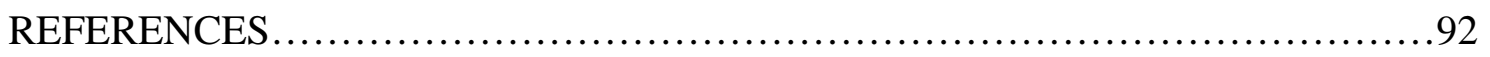

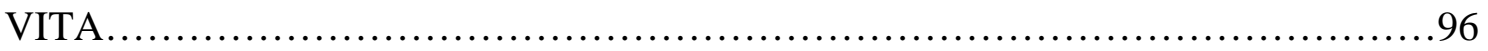




\section{ACKNOWLEDGEMENTS}

Many individuals have helped and encouraged me as I have worked to complete graduate school and the writing of this thesis. I owe them all a huge "thank you."

I would like to thank all of my professors at Cedarville University and Colombia International University who have challenged my thinking and helped me to improve as an educator.

Dr. Ed Baumann, thank you for opening my eyes and mind to the realities of my students lives in the inner-city. Also, thank you for allowing me to first pursue this topic in your Social Diversities class.

Dr. Phil Bassett, thank you for modeling the importance of adapting and creatively modifying instructional strategies in the classroom.

Dr. Stephen Gruber, thank you for providing guidance and instruction on how to approach the thesis writing process.

To Dawn Heideman, my team teacher, thank you for being an excellent teacher. You have inspired me to be better at what I do for the sake of the students with whom we work. This process was possible due in large part to the sacrifice and planning you do in running our successful freshman academy. 
To my administrators, Ed Johnson and Karen Zalac, thanks for using your expertise to implement and run a successful academy program at East High School. Thank you for supporting me as a teacher and us as an academy. You are a vital part in our success.

To my daughters, Petra and Katriella, thank you so much. Even though you are too young to truly understand this undertaking, you have sacrificed much time and attention because daddy was at class or studying. I love you both like crazy!

To my mom, Janet Reini, thank you for your support, encouragement, and training over the years. I owe much of who I am today to you.

To my dad, George Reini, thank you for helping me to learn to think. Thank you for training me from an early age the importance of education.

To my in-laws, Robert and Cynthia Thompson, I am so thankful that I am a part of your family. You have provided so much encouragement for which I am extremely grateful. You both are great role-models for us.

To my Lord, Jesus Christ, thank you for loving me despite who I am and what I do. Your faithfulness is complete and I trust you fully. Thank you for providing strength and encouragement to complete this project. 


\section{DEDICATION}

I am dedicating this thesis to my best friend and wife, Diana. She knows me inside and out and yet she loves me with a devotion that is simply incredible to me. She has supported me completely throughout graduate school. Without her help and undying support I would have never completed this program. Diana, thank you for your love. I love you. 


\section{Chapter 1: Introduction}

\section{Educational Significance}

There exists a well known and well documented academic achievement gap between white students and minority students. The gap is evident in test scores, graduation rates, and appears across the curriculum. It was narrowing through the decades of the 70's and 80's, but, in the 1990's, the gap has widened somewhat. "By the end of high school, in fact, African American and Latino students have skills in both reading and mathematics that are the same as those of white students in the $8^{\text {th }}$ grade." (Haycock, 2001) According to the Ohio Department of Education, the data showing $6^{\text {th }}$ graders who met the minimum state performance standards in reading and mathematics proficiency testing for 2000-01 revealed the glaring disparity amongst racial groups. In the mathematics section, 68.4 percent of white students met the standard compared to 25.8 percent of African American students. In reading, 65.3 percent of white students met the standard compared to 25.0 percent of African American students. (Gehring, 2002) SAT scores revealed the continued inequality into the high school age as the average scores for white students on the verbal and math portions were 506 and 514 respectively in 2001, whereas African American students scored an average of 433 and 426 respectively. (Roach, 2001) The academic achievement gap between white students and minorities, particularly African Americans, is well documented. 
This data calls the researcher to question why this achievement gap exists and persists. There appears to be several factors that play a role in establishing the gap. Some of the factors are student related like poverty, family and community support, and negative peer pressure (Alson, 2003). There are also many factors that involve the school's responsibility for the gap which include high standards, a challenging curriculum, extra help for students, teacher quality, and instructional quality. The focus of this paper will be the school's role in eliminating or at least narrowing the gap.

\section{Purpose}

The purpose of the research is to examine the achievement gap between White students and African American students and to evaluate a specific school structure's effectiveness in narrowing the gap. The researcher will answer the question; does the Academy (school within a school) structure significantly reduce the achievement gap between African American and White students? The research will explain the educational challenges facing the African American student and describe some school related solutions for raising the achievement of these students.

The challenges presented in narrowing the achievement gap and raising equity for all students must be confronted by schools. There is much work to be done and several key issues need to be addressed to improve the quality of education at all schools. Teacher and instructional quality must be a priority especially in high minority school settings where the achievement gap is prevalent. Schools with the most needs tend to not retain effective teachers and administrators. This affects the quality of instruction 
presented and facilitates an increasing achievement gap between white and minority students.

Comprehensive school reform is necessary in many cases so that schools get organized in their approaches to counteracting the gap. Th reform makes possible changes needed in what is taught, how it is taught, and how it is assessed on a schoolwide instead of class by class level (Codding, 2000). Comprehensive school reform affects all aspects at all levels of a school including leadership, management, organization, climate, use of money, and use of human resources. There are many models for comprehensive school reform, but this research will focus on the Academy (school within a school) structure and its' effectiveness in narrowing the achievement gap.

\section{Methodology}

In order to answer the question of the efficiency of various school structures, specifically the Academy model, in improving the achievement gap, the paper will begin with an in depth look at the various literature written on the topic of the achievement gap. It attempts to read and assimilate the views and information out there regarding this topic. It will also attempt to identify possible causes and solutions for the achievement gap. The author accessed most of the previously conducted research through the ERIC database, Academic Search Premier, current journals, and the World Wide Web. 
The method of research will involve a correlative examination of two ninth grade classes at an urban high school whose demographic makeup consists of approximately 99 percent African American students. The classes will be evaluated in terms of state proficiency testing, academic achievement, and attendance. The first class evaluated will be the freshman class during the 1999-2000 school year who were a traditional freshman class. This will be the control group. The second class evaluated will be the freshman class during the 2002-03 school year because they had the full advantages afforded them in an organized, fully functioning Academy called the Freshman Success Academy. This will be the treatment group. Both of these classes will be evaluated to see if there is improvement in achievement with the Academy, and also if the Academy was successful in narrowing the achievement gap between African American and White students.

\section{Biblical Integration}

God created every human in a unique and wonderful way. His plan was very specific as to the natural characteristics, personalities, aptitudes, and abilities according to Psalm 139:13-16. In Galatians 3:28 it says, "There is neither Jew nor Greek (racial differentiation), slave nor free (socioeconomic differentiation), male nor female (gender differentiation), for you are all one in Christ Jesus.” Equity in school is Biblical. This does not necessarily mean that all students should achieve at the same level as every individual is created uniquely. It does suggest that all students should have the same opportunity to achieve. The opportunity should include equity in teacher quality, curriculum quality, quality of instruction, and resources that are available. The 
opportunity should be the same for all students regardless of race, gender, or socioeconomic class.

The education professional must be characterized by excellence because the stakes are so high. The profession works everyday with the future lives of children. The work done should be completed in such a way that lives are touched everyday and God is glorified through the efforts and the motivations exemplified in the profession. Colossians 3:23 says, "Whatever you do, work at it with all your heart, as working for the Lord, not for men.” The teaching profession must have people who are willing to work with all of their hearts in helping all students achieve their fullest potential. This is what is honoring to God.

\section{Setting}

East High School in Columbus, Ohio is an urban high school whose population consists of almost all African American students. The school has implemented the Academy structure in the form of Career Academies. This was accomplished through grant money and an initiative called High Schools that Work.

The general model consists of students entering the freshman year in a general college preparatory academy, and then at the end of their freshman year they choose a career academy that lines up with their career goals. The model is data-driven and involves breaking a large school population up into smaller units comparable to schools within a school. Teachers collaborate throughout the year by utilizing a common planning period. The goal is to cultivate relationships amongst and with the students that 
create a safe and warm environment for the students. The purpose is to increase student achievement.

\section{Summary}

The presentation of research will examine the achievement gap existing between White and African American students. The reader will come to understand the breadth of the problem as well as many of the factors playing a role in the achievement gap. The reader will be presented with many of the issues needing to be addressed by schools in the effort to reach all students and raise achievement. The current Academy school structure will be evaluated as to whether or not it is a viable vehicle of comprehensive school reform in raising the achievement of African American students to a level more closely paralleling that of White students. 


\section{Chapter 2: Literature Review}

\section{Significance}

For decades researchers have discussed and debated the lower levels of educational achievement of African-American compared with White students. This achievement gap exists in all school ages. Even when students arrive at kindergarten, the African-American students are considerably behind their White peers in measurable cognitive skills (Nettles, 2003, p.215).

There is an endless list of possible reasons for this racial divide in achievement levels ranging from the following: linguistic incongruities between home and school culture; differing levels of parental involvement; lack of cultural and social capital; lower general socio-economic status; divergent study habits and motivational levels; the fear of "acting white"; lower teacher expectations, and the quantity and quality of material they are exposed to (Nettles, 2003, p. 216).

\section{Statistics regarding the existence of an achievement gap.}

Between 1970 and 1988, the achievement gap between African-American and White students declined continuously until it was cut by fifty percent. Then, throughout the 1990's, the achievement gap began to widen again. To explain this widening of the gap, it is necessary to closely examine what is going on (Haycock, 2001, p.6). 
There are several achievement patterns which are worthy of noting. In 1999, 1 in 100 African-American 17-year-olds can read and gather information from a specialized text (such as a science article in a magazine) compared to 1 in 12 White students. 1 in 100 African-American students can comfortably solve multi-step problems compared to about 1 in 10 White students. The ratio of African-American students to White students who are able to compute fractions, solve percents, and calculate averages was 30 percent to 70 percent. In the 18-24 age group, 90 percent of Whites have either completed high school or earned a GED while the percentage of African-Americans drops to 81. Approximately 76 percent of White high school graduates go directly to college, while 71 percent of African-Americans will go. African-Americans are only half as likely to earn a bachelors degree by the age of 29 as Whites. These statistics do indicate an achievement gap trend between races (Haycock, 2001, p.7).

\section{Achievement Gap Statistics for Ohio Schools}

In Ohio, the statistics are just as alarming. For example, in $7^{\text {th }}$ grade, only 11 percent of African-American students passed all five parts of the states new proficiency test, compared with 43 percent of White students. In 2001, only 59 percent of AfricanAmerican students graduated from high school, compared with 85 percent of White students. Data released comparing sixth graders were as follows: students passing the math proficiency test - 68.4 percent of White students and 25.8 percent of African- 
American students; and students passing the reading proficiency test -65.3 percent of White students and 25.0 percent of African-American students (Gehring, 2002, pp.2021).

Also in Ohio, 79 percent of White $9^{\text {th }}$ graders performed at or above the passing rate for the Ohio $9^{\text {th }}$ Grade Math Proficiency Test, compared to only 38 percent of the African-American $9^{\text {th }}$ graders. This means that 62 percent of African-American $9^{\text {th }}$ graders in Ohio are not passing, compared to only 21 percent of White $9^{\text {th }}$ graders. According to the 2000 National Assessment of Educational Progress (NAEP), Ohio's African-American-White achievement gap falls $11^{\text {th }}$ among all of the states. This puts Ohio in the top quartile among states on the NAEP math assessment (The Education Trust, 2003).

The achievement gap is also apparent in the number of students successfully taking Advanced Placement (AP) courses and the end of the year exams. In 2000-2001, of the students taking AP exams in Ohio, 4 percent of the test-takers were AfricanAmerican and 89 percent of them were White on the Calculus AB exam. Of the students taking the exam, 31 percent of the African-American students earned scores of 3, 4, or 5 (passing scores), compared to 69 percent of White students. On the AP English Language and Composition exam, 5 percent of the test-takers were African-American and 90 percent were White, and, of those who took this exam, the number of passers was similar - 31 percent African-American and 68 percent White. Finally, in the AP Biology course, 4 percent of the course-takers were African-American and 85 percent were White. 
The number of students passing the exam was as follows: 15 percent of the AfricanAmerican students and 57 percent of the White students passed (The Education Trust, 2003).

Data gathered from the SAT college achievement test also indicated a gap between African-American and White high school seniors. On the math portion of the test, the average score in 2001 for White students taking the test was 531 compared to an average score of 426 for African-American students. The gap is obvious in the average verbal scores as well; White students earned a 529 while African-Americans earned a 433 average score. College Board President Gaston Caperton responded to this data saying, "The score gaps for different racial, ethnic, and socioeconomic groups that we see on the SAT also appear on virtually every measure of achievement, including other standardized tests and classroom grades, and they show up as early as fourth grade. These differences are a powerful illustration of a persistent social problem in our country: inequitable access to high-quality education (Roach, 2001, p. 12).”

According to two international surveys, the Trends in International Mathematics and Science Study (TIMSS) and the Program for International Student Assessment (PISA), the gap between low achievers and average students persist internationally. The gap does not seem to be dependent upon the wealth and prosperity of the country. Wealthier countries such as Portugal, Italy, and the United States have a much higher achievement gap than many poorer countries such as South Korea. The study notes that 
student achievement seems to be closely linked to the students' family backgrounds (Borja, 2002, p. 10).

Data indicates the achievement gap is accompanied by a teacher gap. Quality Counts 2003 is a report, compiled by Richard Ingersoll of the University of Pennsylvania, analyzing public school students' access to qualified teachers. The data reveals 32 percent of high school students in high-poverty schools take a class with a teacher that did not even minor in the subject that he or she teaches, compared to only 22 percent in low poverty schools. This percentage increases to more than 50 percent in the middle school grades in high poverty schools, compared to 44 percent in low poverty schools. 70 percent of students in low poverty secondary schools have teachers who have both majored in and become licensed in the subjects they teach, compared to about 50 percent of high poverty schools. Finally, students in high poverty schools are more likely to be taught by less-experienced teachers. Less than 9 percent of teachers in low poverty schools have fewer than 3 years of teaching experience, whereas more than 13 percent of teachers in high poverty schools have little teaching experience (Heimel, 2003, p.18).

The issue of "white flight” to non-public schools and its' affect on public schools is a possible concern which may be affecting achievement in certain school settings. After several statistical analyses, there does seem to be a correlation between the percentage of white students enrolled in non-public schools and the concentration of minorities in the public schools. Secondly, white enrollment does make a difference in 
the public schools. "The black-white gap is greater in districts with many whites in nonpublic schools (Bankston, Caldas, 2000, pp. 539-550).”

\section{Analysis of the Statistics.}

Historically, African-American youth have been thought to have done better if they adopted a Eurocentric cultural value system. In order for them to achieve, they had to "act white." The findings of this study were these students showed high self-esteem and achievement goals in conjunction with Afro-centricity. The findings revealed that when achievement test scores were the measure of performance, the low scores were associated with the Eurocentric racial attitudes. On the contrary, high self-esteem and achievement goals were associated with an Afro-centric view of self (Spencer, 2001, pp. 21-30).

A study was completed that measured the gap between ethnic groups by assessing data on the National Assessment of Educational Progress (NAEP) and SAT results. It offered an in depth look at the available data on the Black-White and HispanicWhite gap in the areas of reading and mathematics. It sought to answer the question as to why the gap seemed to decrease in the 1970's and early 1980's but then appeared to widen again in the 1990's. The study addresses many factors perceived as reasons for these phenomena such as: changes in socioeconomic and family conditions, changes in youth culture and student behaviors, and changes in schooling conditions and practices.

The study concludes that much ground overall has been covered in narrowing the racial and ethnic gap over the last three decades. It appears that many of the gains made during 
the first two decades occurred at the basic skills level and then the gap grew again when the emphasis shifted toward the advanced skills level during the 1980's. The study states that the factors that have been attributed to the gap do not easily explain the current widening of the gap and that further research is necessary across multiple fields of study (Lee, 2002, pp. 3-12).

Another study attempted to identify if after school activities affected achievement of $8^{\text {th }}$ and $10^{\text {th }}$ grade students and students of different ethnicity. They looked at the two opposing views on the subject - zero-sum concept (extra activities just take time away from students that they should use to study) and the view that these activities provide an experience that contributes to the overall development of the student. The study used the National Education Longitudinal Study (NELS 1988) and it included $8^{\text {th }}$ and $10^{\text {th }}$ grade students whose data on the test were complete. The study evaluated the students' scores in several content areas and categorized the students' pursuits on the basis of in or out of school, academic or nonacademic, and organized or nonorganized. The study concluded that academic pursuits seemed to be consistently related to achievement, while nonacademic pursuits were not significantly related to achievement. These results indicated that the affect was different among differing ethnicities, but it did not go into any depth with this observation (Schreiber, 2002, pp. 10-100).

Another study compares the educational expectations of parents and the influence these expectations have on students of different races. The authors differentiate between the whites and the African-American/Hispanic in that the expectations are generally 
higher. The exception to this is the African-American father due to the lack of a father figure in most cases. The conclusion was as follows: "As we have shown, the aspirations of close relatives and parents, but not those of teachers and peers, have differential effects on students' educational expectations, pointing to the importance of examining the unique family and social contexts in which students of different races live in America (Cheng, 2002, pp. 306-327).”

In another study, evidence is described which shows achievement gaps in mathematics between Black and White students. The study also examined how the socioeconomic status (SES) of the students affects the gap. It found SES had little affect in the disparity of achievement levels. The gap had narrowed for nearly two decades during the 1970's and the 1980's, but started widening again during the 1990's. The researcher evaluated the differences in instructional practices in primarily white and black classrooms. The research identified some key differences in instructional belief and practices between teachers of White and Black students. Teachers of White students focused more on reasoning skills and problem solving, whereas teachers of black students focused on single solution and drill-based instructional strategies. There were also discrepancies found in student course taking and beliefs between these two groups. The study concluded there are disparities between Black and White students' achievement, and this is regardless of their SES status (Lubienski, 2002, pp.269-287).

Another study took a quantitative approach to show evidence that, for black and white students, environment (American vs. foreign born) plays a decisive role in 
determining their success in precalculus. They showed the preparation in "Later Skills" (the math skills most necessary for success in advanced math courses) was further achieved by those who were foreign born. The study involved a sample from a public university in New York with 2,005 students who were broken down by gender, ethnicity, age, and birthplace. The instrument used was a CEEB Elementary Algebra Skills Test. The study took place at a four year college. They then compared the scores achieved on the test to the grade performance in precalculus. The conclusion was that foreign-born students were better prepared than American Whites, Blacks, and Hispanics in the "Later Skills." Therefore, the results point to the environment playing a decisive role in the development of “Later Skills” and, thus, subsequent success in precalculus (Baranchik, 2002, pp. 253-267).

Even long after the 1954 U.S. Supreme Court decision in Brown v. Board of Education, segregated schools continue due to a combination of continued residential segregation and the tradition of neighborhood school assignment. Over 67 percent of African-American students attend majority minority schools and 33 percent attend schools with more than 90 percent minority enrollment. On the other hand, over 90 percent of White students attend school in White majority districts. This has led to serious negative ramifications for most African-American students. Majority minority school districts have a more difficult time attracting and retaining qualified teachers. Oftentimes students are not offered access to advanced coursework and information about college entrance requirements (Nettles, 2003, pp. 218-219). 


\section{What students say/think about the Achievement Gap.}

The way students think and feel is important to consider. In order to close the achievement gap in math and science, we must first give students the confidence and the opportunities to succeed. Courses should be offered to prepare students for standardized tests, and the importance of these tests should be emphasized to minority and low income students. Parent's help and involvement should be solicited as part of their child's education. Schools should provide "Summer Bridge" learning opportunities and mentor programs to link student's educational experiences to the world of work. Students should be provided with every possible resource and opportunity to help them achieve academic success (Hrabowski, 2003, pp. 44-48)

Good teaching is extremely important and has been shown to impact the achievement of students. A study evaluated teachers through the eyes of students in an urban school setting. The students interviewed spoke of good teachers who held high expectations for them and held them to that high standard. The students stressed the importance of good teaching that results in learning. The students also spoke favorably of the block schedule claiming they learned better because the schedule forced teachers to become better at teaching. "Students simply wanted good teachers because such teachers made them learn - often in spite of themselves (Corbett, 2002, pp. 18-22).” 
Oftentimes, minority students are not aware of the perception their school and race achieves far below the standard. When the data was revealed to students in a Philadelphia inner-city school, the students gave the following primary responses as reasons for the lower scores: 31 percent indicated the students held themselves responsible, 24 percent referred to teacher behavior, 18 percent indicated their parents' role, 13 percent discussed the schools themselves, and 11 percent referred to the students' environment or community. They also included poverty and peer pressure in their responses. The students described teachers as unsupportive - "they just hand out the work and expect us to do it without doing much teaching." The students wanted their parents to take a more active role in being involved in their education. The students wanted schools to hold them to higher expectations and provide curriculum that was challenging. Many of the students felt trapped in their home environment, and they felt that if they tried to improve their performance then they would be perceived as "acting white.” Communities and schools must come together, decide what they value for young people, and support that with all of their effort (Taylor, 2003, pp.72-75).

\section{Identifying the Causes for the Gap.}

Society and adults tend to claim the reasons for the achievement gap between races can be traced back to things outside of the school's control, such as, lack of familial support, low socio-economic status, and lack of adequate basic needs (food, clothing, etc.). Students tend to communicate some different sources for the gap, such as, poorly prepared teachers, low expectations, and boring, non-challenging curriculum as bigger 
reasons for the achievement gap. The data seems to support what the students are saying. It shows that education takes the students who begin with less and systematically give them less in the schools. This does not diminish the role outside influences play in the education of students, but, rather, it says that what schools do matters greatly in the lives and education of these “disadvantaged” students (Haycock, 2001, p. 7-8).

Research consistently reports a strong relationship between social class and performance on standardized tests such as the SAT. Many researchers have concluded one avenue through which socio-economic status affects achievement in high school is the academic courses the students take. Historically, high schools commonly placed students and organized their curricula by tracking, where students are placed in a set of courses based on their perceived educational ability. Although many high schools have replaced formal tracking with student choice as the means by which students are placed in courses, the relationship between students' choice and their personal backgrounds resembles that found within traditional tracking curricula (Nettles, 2003, p.217).

Teacher quality is an important issue affecting the achievement gap. As important as qualified teachers are, the amount of out-of-field teachers remains unacceptably high. In 1999-2000 school year, high poverty ad high minority schools had between 29 and 34 percent of core academic courses taught by out-of-field teachers. Poor and minority students are more than twice as likely to serve as a training ground for inexperienced or uncertified teachers as the average child (Jerald, 2002, pp. 1-9). 


\section{Some Solutions for the Gap.}

The focus of education should be placed on the individual learner and on an understanding of the learning process. It should involve sensitivity to the diverse backgrounds of students and a certain level of connectedness between caring teachers and students. The focus should involve the breakdown of fragmented schools and evolve into collaborative efforts between teachers who are no longer isolated from one another. (McCombs, 2000, pp. 29-36).

One school (Francis Bacon) narrowed the achievement gap by first focusing on behavior management and then researched strategies for raising academic achievement. The school concluded it is important to have high expectations for the students and to have a good vehicle for instruction to help the students meet those expectations. Collaboration between teachers is another important component in improving the achievement gap. “An isolated teacher can’t be successful. Teacher collaboration and teacher training are critical.” Another essential element is after school programs that help students to finish their homework. "When students get the right encouragement from a caring person, research shows, they can defy the odds (Quindlen, 2002, pp. 5-8).”

Another important aspect in closing the achievement gap is comprehensive school reform. This includes an overall reorganization laying out high expectations and a specific plan of how the school will achieve those expectations. A high school in California went through this process with great success. "The college board had just 
come out with a report that showed a very high correlation between passing algebra and geometry in high school and later academic success." So this school decided to make this a primary target in their reform process. Math became the backbone for the academic schedule for the students (Codding, 2000, pp. 79-92).

The issue of minority student's attitudes toward math and science achievement is important in reducing the achievement gap and promoting academic success amongst minority students. There is “a striking gap between students' expectations regarding future careers and their understanding of the impact of current course decisions on these plans." Minority students are less likely to attend schools offering advanced placement courses. These students are more likely to encounter negative peer pressure in their decisions to enroll in math and science courses. To succeed in advanced math courses, persistence is necessary, whereas, the basic math courses required for everyone can be passed by students who simply do the work. These courses are not enough to teach the persistence that is necessary for these students to become successful working in a math or science field. "A recent study ... showed that student attitudes toward mathematics are extremely important and play a large part in determining students' motivation toward instruction and achievement.” Therefore, success in math courses and particularly advanced math courses is critical to the academic success of the student (Gilroy, 2002, pp. 39-44).

Title 1, of the Elementary and Secondary Education Act of 1965, has had an effect on the achievement gap particularly in high poverty contexts. During the 1970's and 1980's the gap decreased by about two grade levels. It is assumed that this 
improvement was in direct relation to the funding made available to counteract poverty, and, thus, continued funding is vital to continued improvement in the gap between white and black students. The importance of early childhood education and summer learning opportunities for children in poverty situations needs to continue to be an emphasis of this funding. Comprehensive school reform which focuses on reorganizing and revitalizing the entire school and reducing the student-teacher ratio is another important aspect of this funding (Borman, 2003, pp. 49-53).

The Minority Student Achievement Network is a consortium of 15 school districts with high achievement levels but significant gaps in achievement between white students and their African-American or Latino peers. They have banded together to examine and evaluate data in an effort to emphasize the achievement of students of color. "The Network agrees wholeheartedly that the causes of the achievement gap are neither differences in innate ability nor the result of biased test questions (Kober, 2001),” and the gap is both complex and systemic. The group is concerned with the fact that the Black and Latino students with college educated parents scored lower on a 12th grade reading test than their white peers whose parents only had a high school diploma. They assert that socioeconomic factors account for only part of the achievement gap. The network members agree there are many factors that influence in varying degrees the gap including (but not limited to) racism, poverty, poor educational leadership, low teacher’ expectations, negative peer pressure, etc. (Alson, 2003, pp. 76-78). 


\section{Comprehensive School Reform}

The dominant strategy for school reform has historically consisted of systemic changes to things like standards, assessments, accountability, governance (vouchers and charters), and funding plans. These systemic reforms are policies government at the federal, state, or local levels can prescribe to large numbers of schools. These reforms have little direct influence on the methods and materials used within the classroom to ensure success. Comprehensive school reform shares the goal of systemic school reform - improved student achievement on a broad scale. The difference is comprehensive school reform begins by considering the school as the unit of reform. Ultimately, comprehensive school reform intends to affect every aspect of school functioning. The different models vary considerably, but they all aim to affect curriculum, instruction, assessment, school organization, necessary support for students having difficulties, parental involvement, and sustained professional development for the staff. Because this reform begins at the school level, staff buy-in is critical to establish prior to implementing the reform (Slavin, 2001, pp 22-23).

If a large high school with a high poverty student population has major problems of absenteeism, low test scores, and high drop-out rates, the only solution is a powerful comprehensive school reform which can turn the school around and keep it strong. A comprehensive package of changes establishing new structures and conditions which promote positive human relationships and effective learning opportunities is needed in large, high poverty high schools (Jordan, 2000, pp.159-160). 
The first requirement of reform is to create a school environment which is conducive to learning and to improve student attendance. The school authority must be clearly and visibly in charge of discipline, and they must convey the message that this is a "real school” in which high academic achievement is expected from all students. The reforms must promote conditions where respectful and caring relationships can be developed between teachers and students. Discipline problems should fade so that administrators can rule without resentment. A high priority must be placed on student attendance so that there is the opportunity to increase learning (Jordan, 2000, p. 161).

High schools that are large and departmentalized are often cited as a contributing factor to a climate where discipline is weak and students feel estranged from the school. The teacher to student ratio is so large students who misbehave can become anonymous and escape the regular, effective control of the school (Lee, 1995, pp. 243-245).

Curriculum and instruction must be addressed in comprehensive school reform. The curriculum in large, high-poverty schools is too often unchallenging and uninteresting. Usually, low-level and watered-down courses are offered to everyone except the advanced, college-bound students (Jordan, 2000, p.162). These course offerings continue even though there is a consensus that most students will benefit from a core curriculum with high standards which contains demanding material (Lucas, 1999). Classroom instruction continues to consist of teacher-led lectures and individual worksheets which emphasize drill and practice of isolated facts and formulas. Absent 
from instruction are student learning activities which incorporate cooperative learning and project-based instruction that encourage a deeper understanding of the content and practical applications (Darling-Hammond, 1997).

If staff are expected and encouraged to use new curriculum and try new instructional methodology, they need to receive high-level professional training and direct assistance with their classes. Currently, most secondary teachers teach and learn alone. Professional development and training is a necessary component to successful comprehensive school reform (Jordan, 2000, pp. 162-163).

\section{Talent Development Model}

One model of comprehensive school reform, called the Talent Development Model, was designed to address the problem of large, urban, nonselective high schools. It was researched and developed at Johns Hopkins University and implemented in Patterson High School in Baltimore. This school was chosen for the reforms because it represented one of the poorest educational environments in the state of Maryland (Jordan, 2000, p. 164).

The Talent Development Model contains two organizational reform components. The first is the Academy structure which reduces student apathy and anonymity by creating smaller, more personalized learning communities. The upper grades choose a career focus for their curriculum. The second component is the Twilight School which 
provides recovery opportunities for students with serious discipline problems (Jordan, 2000, p. 165).

\section{Career Academy Programs}

High school career academies were originally designed to address the needs of at risk students. One of the suggested reasons that at risk students do not achieve in school is they feel school is irrelevant to the real world. Career academies bridge the world of academia and the real world of work. A career academy is a type of comprehensive school reform that has several defining characteristics. The academy is a "school-withina-school" in the high school grades run by a small team of teachers from various disciplines. The academy recruits students who volunteer for the program and demonstrate their commitment through an application process. The career academy focuses on a theme in a field in which demand is growing and good employment opportunities exist in the local labor market. The curriculum combines technical and academic courses each semester. The academy includes general employment skills while keeping the option of attending college open to all of its students. The academy provides opportunities for students to be employed part-time during the school year and full-time during vacation times in the field of their academy. The career academy involves representatives from the field of employment to help plan and guide the program. These representatives are involved as speakers, field trip hosts, job supervisors, and mentors for individual students. The academy contributes to the students' sense of membership in a 
caring school community through smaller class sizes than a typical high school, a system of motivation and rewards, and regular contact with their parents. The career academy has the capability of utilizing funds from a variety of community, government, and business sources. A successful career academy is designed with these characteristics as a guide (Stern, 1992).

Each academy is self-contained. They are each led by an administrative team consisting of an academy principal (usually an assistant principal) and an academy instructional leader (usually the department chair of the subject most closely associated with the academy). There is one guidance counselor per academy. To further solidify their unique identities, academies may select banners and mottoes to decorate hallways and staircases (Jordan, 2000, p. 166).

As with any reform movement, several obstacles will exist that must be overcome. Career academies are no exception to this rule. Guidelines for control over the necessary funds to run a successful career academy must be established between the school district, funding agencies, and the staff who implement the program. Apathy amongst the staff must be overcome or avoided in order for a fully functional academy to run effectively. This must be considered as staff are chosen or hired who will be involved in the academy. Union contract guidelines must also be considered in this process. Full administrative support is a critical component in a career academy. These are some of the obstacles that must be considered and overcome when implementing a career academy into a high school (Shorr, 1999, pp. 381-382). 
Collaboration amongst the staff is an important element in a functioning career academy. Common planning times amongst all the staff in the academy are necessary so that weekly meetings can be held to facilitate this collaboration. During this meeting time, the bond between staff can be strengthened while instructional, motivational, and cooperative strategies can be planned (Shorr, 1999, p. 383)

Professional development and training for the staff is another key component for the career academies. Training is necessary in order for teachers to learn to collaborate and educate in a cooperative manner. Special training is also necessary for teachers to learn to integrate the technology required by the academy focus into the curricula for each of their classes (Shorr, 1999, p. 383).

Industry and community partnerships play an important role in a successful career academy. Representatives from the industry by which the academy is focused participate as important partners in all aspects of the career academy. Members of the community also can help staff members make additional connections with other potential industry participants who did not originally share the enthusiasm for becoming involved with high school students who are considered at risk (Shorr, 1999, pp. 383-384).

In career academies, curriculum is developed combining learning outcomes from several disciplines with the advantages of team teaching and computer technologies. The curriculum should be designed thematically to incorporate the technology and principles 
of the career field the academy is based upon. Using technology, teachers can design projects based on the tenets of the career academy by utilizing components of the career academy such as special speakers, field trips, mentors, internships, and parents. Classes are blocked into adjacent time periods to allow for plenty of time to accomplish the tasks and activities associated with a major project. The projects are designed in such a way that they lead up to a culminating senior project that incorporates all that they have learned through their years in the career academy. This senior project would be a large part of a portfolio the students would compile to present to a future employer demonstrating the skills and knowledge they have acquired through participation in the career academy (Shorr, 1999, pp.384-386).

Students follow a block schedule for their classes throughout the day. Students move together from class to class. The block typically consumes either the entire morning or afternoon, and the academy teachers decide on how to divide up the time. Block scheduling allows for more flexibility in class length permitting classes to be longer or shorter, as necessary.

Extra help is available through a variety of avenues in the career academy. Students who obtain a grade lower than a C must participate in tutoring sessions occurring before or after school until their grade rises to a $\mathrm{C}$ or better. The tutoring is also available to all of the students on a voluntary basis. Community volunteers, parents, and retired citizens are recruited to work as tutors for the students (Shorr, 1999, p. 386). 
A mentoring program in which industry, community, and business people are paired up one on one with a high school student is a part of the career academy model. The mentor works with the student and provides guidance, instruction, and an example of how to use education to become successful in life. A study at Colombia University investigated the lives of 100 prominent Americans and found that those who came from a disadvantaged background were especially likely to cite the influence of a mentor as a

key to their success (Rutherford, 1998, pp.78-86). A major goal of the mentoring program is to introduce the students to the world of work as many of them come from poor urban or immigrant families (Shorr, 1999, p.386).

The internship program is a vital link in the career academy between the school training and the labor market. Students are exposed to the world of work and to a variety of opportunities that exist in the field they have chosen. The combination of practical experience and educational training provides motivation to the students and ensures that they receive training that is compatible with the local labor market. Internships usually begin as unpaid experiences, but often lead to paid opportunities (Shorr, 1999, p.388).

\section{Twilight School}

The other organizational component of the Talent Development Model is the Twilight School. This is an after-hours, on-site, short-term alternative program for a small group of students who have serious discipline and attendance issues. Twilight School meets for three hours each day after the regular program is dismissed. The 
smaller classes are for those students who are coming from juvenile justice institutions and court referrals, or for those who have regular confrontations with teachers or other students disturbing the learning environment for the rest of the class. These classes are taught by regular day school faculty who are working on overtime. Students in Twilight School take three academic courses which are the same as day school courses so that they can return to day school any time they are ready (Jordan, 2000, p. 170).

\section{Outcomes of Career Academies}

Schools that have implemented career academies have reported positive results. Hollywood High School, in Hollywood, CA, (78 percent minority population and 85 percent free or reduced lunch population) gives testimony to improved results in several key areas. There was an 83 percent graduation rate for those students who completed the academy program compared to 35 percent that were not in the program. The senior project generated enough enthusiasm that 100 percent of participating students completed the project satisfactorily. More than 65 percent of the students received scholarships to 2- and 4-year colleges and universities (Shorr, 1999, pp. 388-389).

In other studies of career academies, similar positive results were reported. Attendance rates increased by between 10 and 20 percentage points which probably accounts for the improvement in grades and graduation rates (Elliott, 2002, p. 88). 


\section{Possible Reasons Why Career Academies Promote Higher Achievement}

One of the more obvious reasons career academies seem to be effective is the identifiable core of teachers and students that belong to the academy. Teachers identify themselves with the academy, regardless of whether they have classes containing only academy students. These teachers know who the academy students are, share information about these students, and intensively tracks these students' behavior and absences - even more so than for other non-academy students (Hanser, 2000, p.33).

Even more important than the teachers who identify themselves with the academy, the students identify themselves as being a part of a special program. Students express their feelings toward the academy as a tight-knit, family unit. Students are aware of the fact that the teachers share information about them and monitor their progress and development. Students notice the increased attention they receive both inside and outside of the classroom. They recognize more positive communication between their teachers and parents. While the vocational opportunities afforded to the students through the career academies may motivate students, research indicates that the nurturing environment offered to students in this atmosphere is the major factor in improving achievement (Elliott, 2002, pp. 88-89). 


\section{Chapter 3: The Effectiveness of Career Academies}

\section{Introduction}

Over the past twenty years, there has been extensive research on education reform focusing on the achievement gap between white and minority students. East High School in Columbus, Ohio, an inner-city school whose demographics are 97 percent AfricanAmerican, has implemented a possible solution to improve student achievement within the school and to narrow the achievement gap between African-American and White students. The program, which has been implemented into four low performing high schools in Columbus, is called Columbus Pathways to Success Initiative. This program is based on research-based model called the Talent Development model out of Johns Hopkins University. The comprehensive reform model was implemented at East High School and was structured by High Schools That Work, a non-profit comprehensive school reform organization that is funded by grant money.

\section{Columbus Pathways to Success Initiative (CPSI)}

CPSI is a high school reform model developed in 1999 based on High-SchoolsThat-Work and other nationally recognized reform models. This initiative is a collaborative effort between the Columbus Public Schools, the Columbus Chamber of Commerce, Columbus Education Association, Columbus State Community College, and other post secondary institutions. It was initiated by the Chamber of Commerce as an 
effort to develop the future workforce within Columbus instead of drawing people from other places. The rationale for the school system is to improve the student retention rate and to improve student achievement. There are several components within the CPSI which include the following: Freshman Success Academy, Acceleration Academy, a summer bridge program, career academies, teacher advisement program, staff development, public relations, data collection, analysis, and recommendations.

\section{High-Schools-That-Work}

There are several key practices that are adopted by schools that follow this model of school reform. High-Schools-That-Work (HSTW) is a comprehensive reform grant that works with the school and provides funding to implement these practices. It provides professional development for staff and funding for extra positions and programs necessary for this reform to be successful.

There are three goals of HSTW. The first goal is to increase achievement in mathematics, science, communication, problem-solving, and technical skills. Another goal is to blend the content of traditional college preparatory courses with quality vocational and technical studies. The third goal is to advance policies and leadership initiatives necessary to sustain a continuous school-improvement effort.

At the high school level, HSTW advocates ten key practices essential for reform to be successful in increasing student achievement. The first key practice is setting high 
expectations and getting more and more students to meet them. Incorporating vocational studies into the regular curriculum is another key practice. The emphasis in these studies is using high level mathematics, science, language arts, and problem solving skills in the modern workplace. The academic studies should increase student access to academics that teach the essential concepts from the college preparatory curriculum by incorporating real-world problems and projects into the lessons. The program of study should be challenging with an upgraded academic core and a major emphasis. The course of study will give students and parents a system integrating school-based and work-based learning. The learning would span across high school and post-secondary studies. The fifth key practice involves teachers working together. Organization, structure, and scheduling should give academic and vocational teachers the time to plan and deliver integrated instruction aimed at teaching high-level content. Another key practice is getting students actively engaged in rigorous and challenging learning. Each student and his/her parent should receive guidance and advisement ensuring the completion of an accelerated program of study. The ninth key practice is to provide a structured system of extra help to enable students with inadequate preparation to complete a high-level program of study. The last key practice advocated by HSTW is to use student assessment and evaluation data to continuously improve school climate, organization, management, curriculum, and instruction. The purpose of this data analysis is to promote student learning and to recognize students who meet performance goals. When these practices are adhered to, reform is successful, student achievement is increased, and the school improves continuously. 


\section{The Talent Development Model}

The Talent Development Model was formulated at Johns Hopkins University and implemented into a few high schools in Baltimore, Maryland. This model incorporates several components which were adapted and used at East High School. The two major components originating in the Talent Development Model used at East High School were the career academies (curriculum with a focus on future career skills) and twilight school (an after-school program for students who are unable to successfully function in a traditional classroom).

\section{Academic Emergency}

As part of the federal government's education reform initiative, No Child Left Behind, schools that meet a certain number of criteria are labeled into different categories. Columbus Public Schools and East High School was in the lowest category, academic emergency. During the summer following the 2002-2003 school year, Columbus Public Schools were moved out of the academic emergency and into the academic watch category on the state report card.

\section{Career Academies}

The model chosen for continuous improvement was career academies. The model organizes large schools into smaller learning communities called "schools within a 
school" or academies. Freshman entering the school are part of the Freshman Success Academy which will be explained in great detail later in the research. Upon successful completion of the freshman year, students are required to select a career academy based on their future interests. The students have four possibilities to choose from which include the following career academies: Health Sciences, Arts and Communications, ACE (Architecture, Construction, and Engineering), and TEAM (Technology, Engineering, and Manufacturing). The students are then organized by academy into smaller groups who travel together between classes and have the same team of teachers in their core-academic classes for three years. The classes are all centered on the theme of their career academy, and the students have opportunities at earning college credit, experiencing valuable internships, gaining important know-how, and learning from a mentor from the business community. Students in the career academies will have the opportunity to earn for free up to 45 college credits and will leave high school with the promise of a job. The career academy gives focus and purpose to the high school academic experience.

\section{Architecture, Construction, and Engineering Academy (ACE)}

The ACE academy focuses primarily on the building trades. As sophomores, the students take typical college preparatory courses in addition to electives centered on the trades including an introductory foundation class for the academy. The students have the 
opportunity to take classes to learn such skills as Auto-CAD, mechanical drawing, and basic construction skills.

After their sophomore year, students have three options within the ACE Academy. They may choose from one of the following: architectural/civil technology, mechanical technology, or structural technology. Then, during their junior and senior years, the students continue to take their college preparatory classes at East, but they spend half of their time at a vocational career center receiving hands-on training in a specific trade. The core academic classes have incorporated into them projects and an emphasis centered on the construction trades. Students have the opportunity to volunteer their time to work on building projects outside of the school setting through Habitat for Humanity and other non-profit organizations. The academy has several business partners in the community that provide opportunities for professional development, field trips, and special speakers. These business partners also provide internship opportunities and mentors for the students. During the summer between their junior and senior years, the students are involved in an internship with a business partner and are enrolled in college classes where they can earn college credit. Students would choose this academy if they had an interest in the construction trades, architecture, or engineering.

Upon graduation, having come through the ACE Academy, the students would be ready to enter a post-secondary institution in any of the following programs: architecture, civil engineering technology, construction management, heating, ventilation, and airconditioning technology. If their goals do not include further education, they would be 
adequately prepared for the work force. Their previous work experience would be such that they would qualify for many jobs requiring such previous experience. Students also have had many opportunities to meet and network with people in the industry. The ACE Academy is sponsored by the Columbus Chamber of Commerce.

\section{Arts and Communication Academy}

The Arts and Communication (A\&C) Academy is for those students who are artistically inclined and would enjoy creating, performing, or writing. The students in this academy would follow a similar college preparatory schedule during their freshman (FSA) and sophomore year as the students in the ACE Academy. Their schedule would include Career Connections during their freshman year and a Foundations course during their sophomore year.

At the end of their sophomore year, students have the opportunity to choose from three different courses of study to follow during their junior and senior years. The first career path is in Communications Media where they would study multimedia, computer graphics, creative writing, and publication. The second career path is the Performing Arts. Students would study music, theatre, and dance (if available). The third career path is the Visual Arts in which students would study art, photography, and design. Students in the A\&C Academy, during their summers, have the opportunity to take college classes and take part in an internship. 


\section{Health Sciences Academy}

Students in the Health Sciences Academy have an interest in a career in the health industry. They have strong science aptitude and a desire to work with and help other people. Their course of study will follow a similar route as the other academies during

their freshman (FSA) and sophomore years. These students follow a rigorous science and math curriculum.

At the end of their sophomore year, students in the Health Sciences Academy have two career paths to choose from in which their course of study during their junior and senior years will follow. The first career path is the Medical Services which would lead to further education and jobs in nursing, lab technicians, EMS, or pharmacy. The second career path students may choose from is Sports and Fitness Management. This path would lead to further education and jobs in sports and fitness management, or athletic training. Students in the Health Sciences Academy also have the opportunity to earn college credit and take part in internships during their summers. The Health Sciences Academy is sponsored by the Columbus Chamber of Commerce. 


\section{Technology, Engineering, and Manufacturing Academy (TEAM)}

The Technology, Engineering, and Manufacturing (TEAM) Academy is for students who want to receive training and education preparing them for careers in designing new products and in the assembly of the products. Again, students follow a similar course of study during their freshman (FSA) and sophomore years as students in the other academies. Students should have strong aptitude in mathematics and computer science. They should enjoy working with their hands, understanding how things work, and designing things.

As with the other academies, students can choose from three different career paths at the end of their sophomore year. The first career path is Electronic Engineering Technology in which students will learn the basics in electrical technology. This path would prepare students to work in the field of electronics or electrical technology. The second career path is Computer Aided Design Technology which would train the students in mechanical drafting, computer aided drafting (CAD), and basic manufacturing and mechanical principles. The third career path is Mechanical Engineering Technology which is similar to the other two paths with the addition of Machining, Hydraulics, and Robotics. The students in the TEAM Academy also have the opportunities to earn college credit, take part in summer internships, and have the promise of a job upon high school graduation. The TEAM Academy is sponsored by the Columbus Chamber of Commerce. 


\section{The Freshman Success Academy}

The research will focus on the Freshman Success Academy (FSA). The FSA is a self-contained school-within-a-school organized around interdisciplinary teams of teachers designed to provide incoming freshman a smooth transition to high school. The rationale for the FSA is to improve student attendance, improve academic success, reduce the drop out rate, and instruction focused on career education. There are many components that are incorporated into a successful FSA.

\section{Teacher Buy-in}

In order for the FSA to be successful, teachers must buy in to the collaborative effort. Teachers must be willing to work as a team to accomplish common goals. Oftentimes, teachers in the academy setting will be required to go above and beyond the contractual expectations of a teacher. General hiring and interview practices ensure that new members of the team do buy-in, but it is crucial for current staff members to cooperate with the team concept.

\section{Lead Teachers}

The lead teacher of the academy plays an important role in the success of the academy. They communicate regularly with both school administration and district administration in order to ensure the academy is functioning and achieving its 
expectations. The lead teacher accomplishes this by attending all scheduled district-wide and school lead teacher/administrator meetings.

The lead teacher of the academy provides necessary leadership within the academy. They clarify team goals and priorities. They facilitate the collection and team analysis of data. The lead teachers plan agendas, coordinate team meetings and documentation of activities. They coordinate all team activities and staff development for team members.

\section{Teacher Collaboration}

Collaboration amongst the team of teachers is a key part in the FSA. The team of teachers involved in the FSA work together very closely in standardizing the experience of the students in all of their classes. In order to facilitate this collaboration, the teachers share a common planning time in which they meet at least twice a week to coordinate their plans (Appendix C). The teachers have a common syllabus (Appendix A) that outlines common expectations, a common grading scale, the teaching philosophies and objectives of each course. There are ten core values that are posted in a visible and creative way in each classroom. These values are emphasized, taught, and adhered to in every classroom as what the behavioral expectations are. Several times throughout the school year the teachers map and integrate their curriculum. They plan cross-curricular projects and activities so that the students receive different academic perspectives on the same project or learning unit. 


\section{Small Learning Communities}

The FSA is organized into small learning communities, called teams, in which students travel in groups to the same classes with the same team of teachers. The academy has a designated location within the building so the students spend the majority of the day in the same section of the school. The FSA is located primarily in the basement of the high school.

\section{Career Connections}

Every freshman within the academy takes an elective course called Career Connections. This course offers the students an overview of possible careers as well as different career development activities. The course is an introduction to the career focused education that is a key component in the academy model.

\section{Communication with Parents}

Communication with the parents is emphasized within the FSA. To open up this communication, teachers participate in home visits during the summer prior to the school year. During these visits, teachers share the student's schedules, discuss values and expectations, and show a promotional video showcasing the FSA. The visits are effective in conveying the educational opportunity available to the student as well as opening 
communication between teachers and the parents. Throughout the school year, parents will receive a personal phone call twice a month from a teacher in the team (Appendix D). A record of these phone calls is kept in a phone log which records what was discussed in each conversation (Appendix J). At the beginning of the year, the parents are invited via phone to an Open House in which the parents are introduced to the entire staff, reminded of expectations, and served refreshments.

\section{The Importance of Academic Achievement}

The curriculum of the FSA is college preparatory. One of the purposes of the FSA is to improve academic achievement of the students. There are several procedures in place to assist in accomplishing this purpose. First, there is a weekly grade check for the students where each teacher communicates the current grade the student has in that class. This occurs Monday or Tuesday of every week, and its purpose is for the students to have current and regular feedback in each of their classes. In order to regularly evaluate the progress of the freshman class as a whole, data is collected and evaluated on a weekly basis (Appendix E and F). The data includes attendance, parental contact, discipline, and the number of students with A's or B's and F's. At the end of the first semester, students are called in with their parents for a conference with the team of teachers to review a credit check sheet. The credit check sheet (Appendix B) is a paper with all of the core courses and electives listed as well as the grades and credits earned by that student for the first semester. The teachers use this opportunity to explain the progress of the student so far, communicate areas of weakness where the student may 
have fallen behind, and remind them of the importance of being successful in all of their classes as a freshman. For instances where there are persistent behavioral, academic, or social problems, the team calls an intervention meeting. The parent's attendance is requested by phone, and then teachers and oftentimes the social worker meet with the student. Strengths of the student are shared and discussed first, followed by a discussion of the problem(s) that persist. The student is given an opportunity to share any concerns that he/she might have, and then a plan is laid out to correct the current problem (Appendix K). A follow-up meeting is scheduled to discuss progress or the lack thereof in the specified area.

Another important piece in the FSA regarding academic achievement is the free extra help that is available to all students. Math classes are double blocked throughout the year to make certain that all students receive the necessary instruction to catch them up if necessary and to ensure success in their future high school math courses. There also are available Career Based Intervention (math assistance) classes for those who come into high school lacking the basic math skills necessary to be successful in high school math. Also available to the students is after school tutoring in all of their core academic courses. Students may go as often as they need and stay as long as they need to guarantee that they understand and remain caught up in their studies. 


\section{Attendance Policy}

Attendance is a priority in the FSA. In order for students to achieve academically, they must be in school on a regular basis. This priority is emphasized in each of the core academic courses by making attendance a significant part of the grade received. The students receive ten points each day for being in class on time which accounts for 15 -20 percent of the overall grade in each class.

\section{Small Class Size}

A priority of the FSA is to maintain small class sizes to ensure good individual attention for all of the students. The teacher to student ratio is 1:25 or smaller. This is also part of the smaller learning communities.

\section{Acceleration Academy}

Acceleration Academy is an important piece of the reform model affecting student achievement. Acceleration Academy is an after hours "safety net" program designed to help students who have a difficult time adjusting to high school. Students can be assigned, with parental approval, to the Acceleration Academy if they struggle 
with attendance, behavior, or academics in the traditional daytime high school classroom. The classes meet from 2:00 pm until 6:00 pm every day.

The rationale for the Acceleration Academy is to reduce the number of distractions for the other students in the day program, and to provide the necessary skills for these students to be successful in the day program. This program provides an alternative environment with more extensive support services in order to increase opportunities for student achievement. As students experience success in this environment, the drop out rate is reduced.

There are many components that make the Acceleration Academy unique and successful. Students will receive instruction in math, reading/language arts, and study skills. There is also tutoring for the Ohio Ninth Grade Proficiency Tests. The student to teacher ratio is no more than 1:15. Students are assigned for a mandatory minimum of one semester in which they can earn credits, and, if they are successful, they may return to the day program. Since the academy meets after school, transportation is provided to students who need it. If students return to the day program, they are monitored and mentored to ensure a successful return. It is possible for students to make up credits they have previously lost. 


\section{Summer Bridge}

Summer Bridge is another "safety net” program designed to provide reading, math, and study skills to incoming freshman. The rationale for the program is to improve math and reading skills, improve study skills for the rigor of high school, and introduce students to post-secondary education and career opportunities.

There are several important components that make up the Summer Bridge program. Math and reading acceleration are components that help to ensure future success in high school with these vital skills. Study skill techniques are also taught during Summer Bridge. Students receive extra opportunities to take the proficiency test if they attend this program. Students can attend at no cost to them or their parents, and they receive free transportation and free breakfast.

\section{Ohio Ninth Grade Proficiency Tests}

The State of Ohio administers a ninth grade proficiency test in the areas of Reading, Writing, Citizenship, Mathematics, and Science. Students are required to pass all five parts of the proficiency test in order to graduate from high school. These tests are a priority within the FSA. The thinking is that if a freshman has passed all or most of the tests as a freshman then their probability of successfully graduating from high school increases dramatically. Therefore, a good amount of time is devoted to preparing the students for these proficiency tests. In the math classes, the math teachers organize the 
students based on whether or not they have passed the math proficiency test. The students that have not passed the test remain in the classroom and receive extensive instruction and preparation for the test. The students who have already passed the test (and do not have to take the test again) go to work on a hands-on project that is an extension of the classroom curriculum. These students have the opportunity to work on projects that the regular classroom and routine would not be able to facilitate like building balsa-wood bridges and working with graphing calculators. This makes it possible for the students who need the extra instruction in order to pass the proficiency test get it without boring the students who have already passed.

\section{Rewards and Motivation}

Another important piece in the FSA is motivating students on to success and then recognizing them for success. There are many different ways in which students are motivated and rewarded for doing the right thing academically and behaviorally. In each class, teachers have tickets to give to students for doing something good (Appendix G). This may be something as simple as answering a difficult problem correctly, a random act of kindness, or doing an assigned task well. These tickets are stored in a ticket bin, and each week the teachers draw five names out of the bin. The students whose names were drawn receive the opportunity to choose a prize out of the prize drawer which is stocked with an assortment of prizes such as candy, candles, school supplies, make-up, school spirit items, etc. The teachers are responsible for keeping the prize drawer well stocked. All of the tickets not drawn that week then go into a separate bin that will be 
drawn from at the award assemblies for much larger prizes such as sweatshirts, DVD players, boom boxes, etc.

\section{Awards Assemblies}

Four times per year, after each nine week grading period, award assemblies are held to honor student achievement (Appendix H). Once again, parents are invited over the phone to attend and see their child receive an award. At the assembly, awards are handed out recognizing achievement in the following categories: perfect attendance, outstanding scholar (honor roll), most improved student, outstanding student (exceptional academic and behavioral performance), and 110 percent (hardest worker award). Many students may receive a certificate for performance in each category, but then one student is voted as the overall winner in that category by the teachers. The winner receives a certificate, a reward (usually a sweatshirt, purse, or something similar), their picture on the school web-site, and their name on a plaque displayed in a trophy case in the hallway at school. Any student that earns a 4.0 (straight A's in all subject areas) receives a t-shirt with their certificate. Throughout the award assembly, names are drawn from the ticket bin for various prizes. The last assembly of the year is a picnic at a park near the school. These assemblies are a celebration of student accomplishment that is enjoyed by parents and students alike. 


\section{Honor Roll Students}

There are special opportunities for students who make the honor roll for a nineweek grading period. First, they receive a certificate and recognition at the awards assembly (Appendix I). Secondly, a church in the surrounding neighborhood sponsors a free breakfast for the honor roll students in which they invite special speakers who are both community leaders and East High Alumni. Finally, they receive the opportunity to participate in the Honor Roll Sponsorship Program. This program allows each of the honor roll students to choose a fellow student who did not make the honor roll with whom to partner. If the honor roll student maintains his/her honor roll status while pulling their partner up onto the honor roll, then both students receives a free t-shirt and a pizza party. This program provides motivation for the students to stay on honor roll while helping a fellow student to achieve this status. Honor roll is a significant achievement, and it should be duly recognized and aspired to.

\section{Hand Prints}

Success on the Ohio Ninth Grade Proficiency Test is a very important aspect in determining the success of the FSA. Therefore, when students achieve in this area by passing each part of the proficiency test, they are afforded the opportunity to be recognized for many years to come. For each area of the proficiency test in which the student passes, they place their handprint on the wall of the classroom that corresponds to 
the section that they passed (for example, if they passed the math section, then they would place their handprint on the wall in their math classroom). The handprints will remain on the wall for all to see indefinitely.

\section{Cleveland Trip}

Towards the end of the year, the entire FSA will be rewarded for their efforts with an all day trip to Cleveland. The staff and students travel to and from Cleveland in luxury charter buses. In Cleveland, they spend the morning touring a historical cemetery and an African-American museum. Then they board a luxury boat for a lunch cruise out onto Lake Erie. On the boat, the staff and students are treated to an all-you-can-eat buffet, music, and a DJ. There are academic assignments aligned with the trip, but it is primarily a reward for a great school year.

\section{Team T-Shirts}

As a way of building team pride within the FSA, each year team t-shirts are designed. Everyone (staff and students) are required to purchase one to wear to all of the award assemblies and the Cleveland trip. The t-shirts can be purchased in orange or black (school colors) and have "Property of East High" on the front and the motivational slogan for the year on back. 


\section{Pilgrim Mentoring}

Mentoring programs are another opportunity promoting success in the lives of students. In the career academy, the students will receive mentoring from a business person, but in the FSA the students are required to become a mentor to an elementary age child who struggles with academics. Pilgrim Elementary School is a feeder school for East High School. The elementary school is in academic emergency. The FSA has instituted a mentoring program in which the ninth graders are paired up with a child in the first through sixth grade who is need of help. Each Monday afternoon, after school, the ninth graders walk down to Pilgrim Elementary School to spend 45 minutes working with a child who is assigned to them for the year. During this time, the child must spend twenty minutes reading out loud and writing sentences based on what they have read. The ninth graders then work with the children on any other school work their child needs to finish. The students have established many strong relationships with their child and are hopefully increasing their chance of success in the classroom. The freshman do receive community service hours in return which they need for graduation.

\section{The Research Process}

While there are several factors that may contribute to the achievement gap such as socio-economic status, lack of family/community support, poor school conditions, etc., the researcher will focus on the differences between the racial disparities. The researcher 
will explain the overall program that has been implemented and analyze the results by making two separate comparisons. The comparisons will evaluate data that was gathered during two different academic years, 2000-01 (pre-academy) and 2002-2003 (fullyfunctional academy). The researcher will analyze data from these years to compare the results within the school to evaluate the academy's effectiveness within the school as well as to compare the results with the white population within the State of Ohio to evaluate the academy's effectiveness in narrowing the achievement gap between White and African-American students.

\section{Results within the School}

There are several important statistics that are analyzed to evaluate the success of the academy. The first data set that is evaluated is the attendance rate. During the 200001 school year, the attendance rate for the freshman class was 73 percent, and, during the 2002-03 school year, the attendance rate increased to 86 percent.

Results on the Ohio $9^{\text {th }}$ Grade Proficiency Test improved in every subject area significantly between the 2000-01 and 2002-03 school years. There was continuous and consistent improvement in the rate of students who passed in all five sections of the proficiency test. The following chart demonstrates the progress of passing rates as the academy model was implemented into the school. 


\section{Ohio $9^{\text {th }}$ Grade Proficiency Test Scores}

\begin{tabular}{|c|c|c|c|}
\hline Test & $\mathbf{1}^{\text {st }}$ Year & $\mathbf{2}^{\text {nd }}$ Year & $\mathbf{3}^{\text {rd }}$ Year \\
\hline & $\underline{\mathbf{0 0 - 0 1}}$ & $\underline{\mathbf{0 1 - 0 2}}$ & $\underline{\mathbf{0 2 - 0 3}}$ \\
\hline Writing & $76 \%$ & $77 \%$ & $91 \%$ \\
\hline Reading & $69 \%$ & $73 \%$ & $79 \%$ \\
\hline Math & $35 \%$ & $44 \%$ & $54 \%$ \\
\hline Citizenship & $55 \%$ & $58 \%$ & $70 \%$ \\
\hline Science & $37 \%$ & $38 \%$ & $46 \%$ \\
\hline
\end{tabular}

These results represent students who were first year freshman at East High School during that school year. There is consistent improvement in all areas of the proficiency test after the implementation of the academy model.

The failure rates decreased in all of the core academic subject areas during these same school years as the following chart demonstrates. The percentages represent the number of students taking the course that earned a failing grade and, therefore did not receive credit for this required course. 


\section{Failure Rates}

\begin{tabular}{|c|c|c|c|}
\hline & $\underline{\mathbf{0 0 - 0 1}}$ & $\mathbf{0 1 - 0 2}$ & $\underline{\mathbf{0 2 - 0 3}}$ \\
\hline English & $32.7 \%$ & $30 \%$ & $3.2 \%$ \\
\hline Science & $33 \%$ & $23.5 \%$ & $14.7 \%$ \\
\hline Social Studies & $28 \%$ & $28 \%$ & $17.9 \%$ \\
\hline Algebra & $28 \%$ & $33 \%$ & $17.9 \%$ \\
\hline
\end{tabular}

The decreasing number of failures, combined with the improved attendance rate and improved success on the proficiency tests, were a large factor in improving the matriculation rate. The matriculation rate for the Freshman Success Academy is defined as the number of students who received enough credits to make them legitimate sophomores at the end of their freshman year. The matriculation rate for East High School freshman improved from 52 percent at the end of the 2001-02 school year to 68 percent at the end of the 2002-03 school year.

There were some other statistics that were indicative of the large number of students who succeeded in the F.S.A. atmosphere. There were 180 freshman enrolled in the F.S.A. Of those students, an average of 7 percent earned a 4.0 G.P.A. (straight A's) each of the nine-week grading periods. An average of 15 percent earned at least a 3.5 G.P.A. each nine-week grading period. An average of 44 percent earned at least a 3.0 
each nine-week grading period which placed them on the school's honor roll. These numbers indicate that a large number of students thrived while enrolled in the F.S.A.

\section{Statistics Comparing East High School with the State of Ohio Disaggregated by Race}

The following statistics were generated through the Ohio Department of Education website. The website makes available data and a statistic-generating program called Microstrategy. This program contains data from the State of Ohio, Ohio’s schools, and school districts, and it allows generation of comparative statistics. The address for the website is www.ilrc.ode.state.oh.us/Microstrategy.

\section{Attendance Rates Results Disaggregated by Race}

Attendance Rate - Building and District

\begin{tabular}{|c|c|c|c|c|}
\hline \multicolumn{2}{|c|}{ East High School Attendance Rate } & \multicolumn{3}{|c|}{$\begin{array}{c}\text { Columbus Public Schools Attendance } \\
\text { Rate by Race }\end{array}$} \\
\hline $2000-01$ & $2002-03$ & \multicolumn{2}{|c|}{$2000-01$} & $2002-03$ \\
\hline $78.5^{*}$ & $86.6^{*}$ & White & 89.9 & 93.3 \\
\cline { 3 - 5 } & & Black & 90.4 & 92.7 \\
\cline { 2 - 5 } & & & &
\end{tabular}

*East High School's racial composition is almost 100\% Black 


\section{Attendance Rate - State of Ohio}

\begin{tabular}{|c|c|c|c|}
\hline \multicolumn{2}{|c|}{$2000-01$} & \multicolumn{2}{c|}{$2002-03$} \\
\hline White & 94.5 & White & 94.5 \\
\hline Black & 91.2 & Black & 93.1 \\
& & & \\
\hline
\end{tabular}

The achievement gap is not obviously reflected in the attendance rates at the district and state level. There is a noticeable gap between students who attend East High School (almost exclusively African-American) and all the other White students in the State of Ohio. There is a significant decrease in this achievement gap during the time between the 2000-01 and the 2002-03 school years. The gap decreased from 16 percent during the 2000-01 school year to 7.9 percent during the 2002-03 school year. The increase in attendance at East High School may partially account for the increased academic achievement.

\section{Proficiency Results Disaggregated by Race}

The following chart shows the results of all five parts of the Ohio Ninth Grade Proficiency Tests for 2000-01 and 2002-03. It compares the freshman students attending 
East High School (comprised of almost all African-Americans) with both the Black and White students across the State of Ohio.

\begin{tabular}{|c|c|c|c|c|c|c|}
\hline & \multicolumn{2}{|c|}{ East High School } & \multicolumn{2}{|c|}{$\begin{array}{l}\text { State of Ohio - } \\
\text { Black Students }\end{array}$} & \multicolumn{2}{|c|}{$\begin{array}{l}\text { State of Ohio - } \\
\text { White Students }\end{array}$} \\
\hline & $2000-01$ & 2002-03 & 2000-01 & 2002-03 & 2000-01 & 2002-03 \\
\hline Writing & $76 \%$ & $91 \%$ & $80 \%$ & $80 \%$ & $94 \%$ & $90 \%$ \\
\hline Reading & $69 \%$ & $79 \%$ & $76 \%$ & $75 \%$ & 94\% & $90 \%$ \\
\hline Math & $35 \%$ & $54 \%$ & $38 \%$ & $42 \%$ & $79 \%$ & $78 \%$ \\
\hline Citizenship & $55 \%$ & $70 \%$ & $59 \%$ & $62 \%$ & $87 \%$ & $86 \%$ \\
\hline Science & $37 \%$ & $46 \%$ & $46 \%$ & $48 \%$ & $85 \%$ & $81 \%$ \\
\hline
\end{tabular}

The results indicate that gains were made over these years in decreasing the achievement gap between White and African-American students. As previously stated, the academy structure significantly improved the results in every area within the school. The results also indicate that the school made more progress in each area when compared to the other Black students in the State of Ohio. In fact, East High freshman had considerably more students pass each area of the proficiency test in 2002-03 except for the science section in 2002-03 than did all of the other Black students across the State of Ohio. 
It is necessary to examine the effect the academy structure at East High School had on the achievement gap between African-American and White students. The achievement gap decreased in every subject area of the Ohio Ninth Grade Proficiency Test. In fact, in the writing section the African-American students at East High School surpassed the number of White students passing this portion of the test. In Reading, the gap decreased from 25 percent in 2000-01 to 11 percent in 2002-03. In the Math section, the achievement gap lessened from 44 percent in 2000-01 to 24 percent in 2002-03. In the Citizenship portion of the test, the gap was decreased by half when it went from 32 percent in 2000-01 to 16 percent in 2002-03. Finally, in the science section, the gap, while it remains very large, did decrease from 48 percent in 2000-01 to 35 percent in 2002-03. The achievement gap between Black and White students was reduced, and in one section eliminated, in all areas of the Ohio Ninth Grade Proficiency Test at East High School.

\section{Significance of the Results}

These results were significant in demonstrating the effectiveness of the academy structure in reducing the achievement gap between African-American and White students. The major change that occurred at East High School between the two years being compared was the implementation and the functionality of the Freshman Success Academy. 


\section{Chapter 4: Perspectives, Conclusions, and Recommendations}

There are five different groups of people affected by the academy model: the teachers, the school administrators, the parents, the students, and the researchers. Perspectives and conclusions from each group will be disclosed.

\section{Perspectives and Conclusions of the Teachers}

The Teacher Questionnaire (Appendix L) was given to seven public school teachers who were directly involved with the Freshman Success Academy at East High School. The teachers who shared their responses have been teaching for the following number of years: $30,1,1,6,15,32$, and 7 . There were two teachers that indicated they have 6 years experience in an academy setting, and the rest had 3 years experience in the academy structure. Their responses will be shared.

Question: "What are the positive aspects, if any, of teaching in an academy?"

The teacher all related how the community of teachers with shared expectations and students allows cross-referencing and cohesiveness with one another. It allows teachers to be unified in dealing with achievement and discipline issues. The common planning time is important to allow time to discuss concerns. The teachers indicated they learn much more about their students in an academy setting. They said students having the same teachers and traveling from class to class with the same group of fellow students 
is a positive aspect. Having common goals helps to unify the teachers. Support is natural when the expectations are the same. Another positive aspect mentioned is the relationships developed with the other teachers that are in the academy.

Question: "What are the negative aspects, if any, of teaching in an academy?"

Many of the teachers indicated that the negative aspects related to time issues. Meetings absorb a large amount of the teachers planning time throughout the week. Phone calls every two weeks to a different group of parents can also take up time. The other issue that seemed to resonate among several of the teachers was that of interpersonal relationships among the team members. It takes a large amount of cooperation, flexibility, and good communication in order for the team of teachers to function together cohesively. If a teacher is assigned to this teaching position and does not buy in to the concept, they will have a hard time working in the team structure. There also was mentioned a concern that the older, veteran teachers' opinions are not considered and valued as much as some of the younger team members.

Question: "How does the academy structure affect student attendance and achievement?”

The teachers stressed the importance of the common planning time in order to accomplish several goals. Attendance can be checked between teachers on a daily basis to see which students are attending some classes but skipping others. The time together 
enables teachers to have a stronger more unified message to the students. The common planning time is also used to bring in parents of students who are struggling academically or behaviorally and meet with all the teachers at once. The students understand that the teachers communicate regularly and that if there is a problem there will be a parent conference either by phone or in person. Another reason for the increased attendance is the positive relationships that are formed between the students and the teachers. Some teachers mentioned that while some progress has been made in the area of attendance, more work can still be done across the board to improve this area. Higher achievement is encouraged through the positive rewards recognizing the achievement.

Question: "What advice do you have for other teachers working in an academy structure?”

Buying into the concept completely and communicating clearly are the two points of emphasis expressed by the teachers. If a teacher does not buy in to or agree with the concept of the academy structure, they will become problematic. It is important to be a team player and do your part in helping the academy to be successful. Do not be afraid to speak up and share ideas. When ideas are communicated, it is important to value all input from every team member. Patience is an important attribute when working with other people. Communicate, communicate, communicate and work, work, work, were also included in the comments. Administrative support is a necessary ingredient for a successful academy. 
Question: "What conclusions have you drawn in regards to the academy structure at East High School?”

The additional support provided to the freshman is crucial in making the transition into high school. It only works well if the teachers buy into the cooperative work structure of the academy. It is the best solution for a very difficult environment. The goals are accomplished much easier with a unified team working towards them, but differences in expectations can cause problems in reaching a consensus. Beware of old vs. young sentiments or any other issues that can divide rather than unify the team. The 4X4 block schedule helps bring academic success to the urban setting.

\section{Perspectives and Conclusions of the School Administrators}

The school administrator questionnaire (Appendix M) was given to two public school administrators who are directly involved in the Freshman Success Academy at East High School. They are the principal of the school who has been an administrator for 22 years, 15 in an academy school and 7 in non-academy schools, and the assistant principal responsible for the freshman who has 13 years, 7 of those years in an academy school, of school administration experience.

Question: "What are the critical components that must be in place within a school in order for the academy structure to be successful?” 
1) Common planning time for core academic teachers in every academy is essential.

2) A schedule that works and is true to the academy model.

3) A committed teaching staff is essential for success. Teacher buy-in and commitment.

4) Support from the business community.

5) Support from higher education.

6) Work based learning.

7) Mentoring program.

Question: "What are the positive aspects, if any, of the academy structure in a school?”

The relationships promoted in the academy structure seems to be the center of many of the positive aspects relating to this model. They include small learning communities with a common core of caring teachers. In these communities, the teachers and students can work together with a common goal. There is a practical focus for the staff and students. Mentoring, internships, and college opportunities in a chosen field while the students are still in high school are all positive parts of the academy model. Also, there is real career exploration that takes place naturally within the application of the academies. 
Question: "What are the negative aspects, if any, of the academy structure in a school?”

The scheduling is much more complicated than the traditional school schedule. Non-cooperative team members can also end up being a negative aspect in the academy. The principal replied that there are no negative aspects associated with the academy model.

Question: “In your experience, how does the academy structure affect the attendance and achievement of the students?”

The teacher/student/parent relationship enhanced in the academy structure positively affects the attendance rate. There is a feeling of "togetherness" that is promoted. So, when the academy model is implemented correctly, attendance and achievement will significantly improve.

Question: "What are your concluding thoughts with regard to the academy school structure?”

This is the only way to go in a large urban school. If students feel welcomed and engaged both academically and socially, they have a much greater chance of being successful. 
"When implemented correctly, it is a way of providing students a supportive environment that allows them to bridge the gap between school and the working world. It allows for the practical application of the academies in a nurturing, caring environment.”

\section{Perspectives and Conclusions of Students}

Ten students who had completed the Freshman Success Academy during the 2002-03 school year were chosen to receive and fill out the student questionnaire (Appendix O). They were also given a copy of the parent survey for their parents to fill out. They were promised a pizza party at lunch if they returned the questionnaires by a certain time. 8 of the 10 questionnaires were completed. The students included six boys and two girls. Their responses are summarized and shared here.

Question: "Describe what things you liked, if any, about the Freshman Success Academy?”

There were several different things that the students mentioned liking in the Freshmen Success Academy. They enjoyed the strong relationships that they developed with their freshman teachers. They liked the fact that if they did not understand something academically, there was always extra help available. They felt the teachers "broke things down" and made them easier to understand. Learning was more fun, and they learned more than they have ever learned before. The students also expressed that 
they could get help with things other than just academic issues - life issues. They really liked the Cleveland trip, the projects, the end of the year picnic, and the awards assemblies.

Question: "Describe what things you did not like, if any, about the Freshman Success Academy?”

One student expressed that at times he did not like the added attention he received. He said, "they are always on your back." Another student mentioned specific teachers they did not like or with whom they did not get along. Yet another student expressed they did not like the other students who did not want to learn or do the work. And several students said they liked everything about the Freshman Success Academy.

Question: "Do you feel that the Freshman Success Academy prepared you to be successful in high school? Explain.”

Only one student responded no to this question. She said that the work was too easy, and that they weren’t given the opportunity to work on their own like they have to as sophomores. The other seven students responded with yeses for various reasons. One student said that the academy allowed the majority of the freshman to mature and become respectful of teachers. Another student said the teachers explained everything that goes on in high school and the importance of their grades in the college process very well. Another student made reference to the extra help available when he had trouble understanding. Several of the students simply said they learned a lot. 
Question: "What would you change, if anything, about the Freshman Success Academy?”

One student replied that she would let the freshman students work more independently. Another student wanted to change the t-shirts. The other six students said that they would not change anything.

\section{Perspectives and Conclusions of Parents}

The parent questionnaire (Appendix N) was delivered to each parent by their child who was also filling out the student questionnaire. Therefore, I received back eight parent questionnaires which contained four questions each. The first three questions the parent simply had to circle a response out of the following choices: I strongly agree, I agree, I disagree, or undecided. The fourth question allowed them to share any comments they had regarding the Freshman Success Academy. Their responses are shared.

Question: “Did you feel as if you were regularly contacted regarding your child’s progress?”

For this question, there were six parents who circled “I strongly agree,” one parent who circled "I agree,” and one parent who circled "I disagree.” 
Question: "Did you feel more involved in your child's education?”

On this question, there were five parents who circle "I strongly agree," two parents who circled "I agree,” and one parent who circled "I disagree."

Question: "Did you think your child's academic achievement improved in the Freshman Success Academy?”

For this question, there were three parents that circled "I strongly agree,” four parents that circled "I agree," and again one parent that circled "I disagree."

Question: "Do you have any comments regarding your child's experience in the Freshman Success Academy?”

One parent had a few negative comments questioning the amount of contact he received from the teachers at regular intervals. He said that he would like earlier notification if his son is not performing well in a class. He also questioned how students were assigned to particular classes. Two parents commented on the great teachers in the Freshman Success Academy. The other five parents did not make any comments. 


\section{Perspectives and Conclusions from Researchers}

The past year and a half of researching both the achievement gap existing between African-American and White students and possible solutions for this gap has been encouraging, challenging, and enlightening. As a teacher of African-American students, the researcher was challenged on a daily basis by the achievement gap. The researcher was forced to evaluate why his students achieved at a lower level and what he could do to improve achievement in his classroom. The findings, especially relating to the academy structure, were encouraging in the results achieved.

The researcher became involved in teaching in the Freshman Success Academy at East High School at the beginning of the 2002-03 school year. He had taught at East High School for one year previous to this experience and had a total of eight years of teaching experience.

In an urban setting, it is critical for schools to organize and structure themselves such that the students feel welcomed and have a sense of belonging. The majority of students come into school with many life issues that make learning more difficult. Therefore, it is imperative for schools to have a strategy for creating a safe and loving environment for the students. This makes the concept and model of smaller schools within a school (academy) a logical strategy for fulfilling this strategy. In order for this model to be successful, there must be some components in place within the school. 
Administrative support is a critical component in implementing a successful academy. Scheduling is more complex to ensure that there is a common planning period for all of the teachers within the academy. As the teachers come up with creative ideas and integrative learning projects, the administration must be willing to work with changes in the schedule and other issues that may arise. They must be willing to allow the caring group of teachers to become creative in their teaching strategies. The administration must recognize the priority that the freshman year is in helping students to transition into high school and propelling them on to future success.

The teachers who teach in the academy are the key to forming and running a successful academy. Teachers must buy into the team concept completely and be willing to communicate and work closely with the other members of the team. They must truly care for the students they are entrusted to teach. They must be willing to work above and beyond what the contract requires for the benefit of the students. They must be willing to spend extra time contacting parents and increasing their involvement. The teachers must be committed to creating an environment where the students feel safe, loved, and accepted and still emphasizing the importance of learning. Without teachers who are committed to these things, the academy will not function any better than a traditional school.

The vast majority of students with regular attendance in the Freshman Success Academy experienced academic and social success. Across the board amongst the freshman, academic achievement increased. This was reflected in the increased 
attendance rate, increased number of students on the honor roll each nine weeks, and increased proficiency test scores. The students received constant reminders of what appropriate behavior and communication looked like in the classroom setting. The expectations and consequences for inappropriate behavior were clearly explained on a regular basis. As a result, discipline problems occurred less frequently.

The researcher has concluded that educators need to address the issue of the achievement gap between African-American and White students by working to find things that schools can do to raise the achievement of all students regardless of race. Educators must evaluate the staff, policies, and procedures of their schools to see if changes are necessary in order to increase achievement. A specific plan must be formulated for each school and steps must be taken to implement and fulfill this plan. The implementation process must be evaluated and tweaked on a regular basis to make sure that the achievement of students remains the priority through each phase of reform. Staff who are not committed to this priority must be moved on if possible. Our goal as educators should be that there is truly no child left behind. 


\section{Appendix A}

\section{Course Title \\ Expectations and Syllabus \\ Teacher's name \\ $\underline{\text { Room \# }}$}

Course Description: Describe the purpose of your class. (See Ms. Luaces's Syllabus for ideas if you're not sure where to start. She's got a great example!)

\section{Goals and Objectives:}

- Using bullet statements, define your goals and objectives for your class.

- Goals may be "to understand and use the five- paragraph essay", or "to determine the differences between truth and propaganda".

- Objectives may be "to discuss works of fiction by different authors", or "to develop an understanding of slavery in America and its psychological, social, economic, and political affects on the United States and the rest of the world.” (Luaces, syllabus)

- Goals and objectives should also comply with proficiency standards and SLCs (if your curriculum has them from the district).

Instructional Philosophy: Here, you will include some of the things you believe in, such as giving equal opportunities for all students; how you will be teaching your subject matter, such as using interdisciplinary instructional methods (cross-curriculum), speaking, writing, reading, discussing, using media, etc.; and your assessment, such as a straight-point scale, quizzes, notebooks, writing assignments, in-class work, and homework.

\section{Class Expectations:}

- By using bullets, we will list our 10 values (as decided by the entire team) also our late policy and pass policy.

- Late policy: 10 pts. for attendance every day. 5 points if student is tardy (not in class after last bell), 0 points if student is absent. Attendance points can not be made up. Teachers: Mark in grade book • for present, for tardy, and $\mathrm{X}$ for absent.

- Pass policy: Ms. Luaces has designed sheets with 3 passes. Students will be given one sheet per 9 weeks. If students use all 3 passes, no more are given for the 9 weeks. If students do not use all passes, extra credit will be given. 20 pts. for all 3 passes, 10 pts. for two passes, 5 pts. for one pass. 


\section{Appendix A (cont.)}

\section{Class Supplies:}

- Using bullets, list your required supplies, such as pen/pencil, paper, book, etc.

- Ms. Heideman and Ms. Tice will be selling pencils in their rooms for .10 a piece.

\section{Grading Policy:}

List your grading policy here. Please do not forget the 10 point per day attendance. Remember, this can't be made up.

Everyone on the Freshman Team will use the same scale for letter grades. List these as follows:

A $90 \%-100 \%$

В $80 \%-89 \%$

C $\mathbf{7 0} \%-79 \%$

D $60 \%-69 \%$
Student exceeded expectations. Student completed and turned in all homework on the scheduled due date. Student completed and highly on all exams and quizzes.

Student met expectations. Student completed most (90\%) of all homework in a timely manner. Student participated in class. Student completed and scored well on all major projects and scored well on all exams and quizzes.

Student is passing, but does not meet stated expectations. Student completed most(80\% or less) of homework assignments in a timely manner. Student completed and scored average on 2/3 of the major projects assigned. Student completed exams and quizzes.

Student is passing, but meets very few stated expectations. Student completed some (70\%) of homework in a timely manner. Student completed one major project. Student may be missing or earned an 


\section{Appendix A (cont.)}

F on 3 or more exams.

F 59\% and below Student failed to meet expectations. Student did not complete homework

projects. Student failed to complete or received a failing grade on exams and quizzes.

Your semester grade will be an average of your grades for each grading period and the grade you earn on your final exam. Your final exam is worth $1 / 9^{\text {th }}$ of your final grade. No student is excused from the final grade for any reason. (Luaces, syllabus)

Homework Expectations: List your expectations here, such as neat, on time, legible, complete sentences, etc.

$\begin{array}{ll}\text { Assignment Heading: } & \text { Name } \\ & \text { Date } \\ & \text { Class } \\ & \text { Assignment }\end{array}$

Make-Up Work: List your policy here. We've discussed only one day late work (no end of semester crunch time), but we've not come to a consensus as of yet.

Major Projects: List any projects for the semester here. 


\section{Appendix B}

NAME

STUDENT NUMBER \#

(THE FOLLOWING 4 CREDITS ARE ALL REQUIRED FOR

GRADUATION AND MUST BE TAKEN IN SUMMER IF NOT PASSED)

ALGEBRA 1 (1 credit) earned failed currently taking $\underline{\text { PROFICIENCIES }}$

$\mathbf{1 9}^{\text {th }}$ C. HISTORY (1 credit) earned failed currently taking PASSED

LITERATURE (1 credit) earned failed currently taking

PHYS. SCIENCE (1 credit) earned failed currently taking
WRITING READING MATH CITIZENSHIP

SCIENCE

\begin{tabular}{|c|c|c|}
\hline \multicolumn{3}{|l|}{ (ELECTIVES) } \\
\hline ART (1 credit) & earned failed & currently taking \\
\hline BAND (1 credit) & earned failed & currently taking \\
\hline CAREER CONNECTIONS (1/2 credit) & earned failed & currently taking \\
\hline CBI (1 credit) & earned failed & currently taking \\
\hline CHORUS (1 credit) & earned failed & currently taking \\
\hline COMPUTER LITERACY (1/2 credit) & earned failed & currently taking \\
\hline FOREIGN LANGUAGE (1 credit) & earned failed & currently taking \\
\hline HEALTH (1/4 credit) & earned failed & currently taking \\
\hline HUMAN RELATIONS (1/2 credit) & earned failed & currently taking \\
\hline JOBS FOR GRADS (1 credit) & earned failed & currently taking \\
\hline MUSIC SURVEY (1 credit) & earned failed & currently taking \\
\hline ON YOUR OWN (1/2 credit) & earned failed & currently taking \\
\hline P.E (1/4 credit) & earned failed & currently taking \\
\hline ROTC (1 credit) & earned failed & currently taking \\
\hline SCAN-TEK (1 credit) & earned failed & currently taking \\
\hline THEATER SURVEY (1 credit) & earned failed & currently takir \\
\hline
\end{tabular}




\section{Appendix B (cont.)}

$* * * * * * * * * * * * * * * * * * * * * * * * * * * * * * * * * * * * * * * * * * * * * * * * * * * * * * * * * * * * * * * * * * * * * * * *$ FIRST SEMESTER TOTAL = SECOND SEMESTER TOTAL = FRESHMAN YEAR TOTAL =

\section{NINTH GRADERS NEED THE TOP 4 CLASSES AND AT LEAST 1 ELECTIVE CREDIT FOR A TOTAL OF 5 CREDITS TO BE A SOPHOMORE}

$* * * * * * * * * * * * * * * * * * * * * * * * * * * * * * * * * * * * * * * * * * * * * * * * * * * * * * * * * * * * * * * * * * * * * * * * * *$

THESE ARE CLASSES THAT ARE REQUIRED FOR A HIGH SCHOOL DIPLOMA:

ENGLISH (4) SCIENCE (3) TECHNOLOGY (1) TOREIGN LANGUAGE (3)

HISTORY (3) P.E.(1/2) INTERNSHIP (1) MATH (3) OTHER ELECTIVES (3) 


\section{Appendix C}

\section{TEAM MEETINGS}

The East High School Freshman Success Academy will hold team meetings every Tuesday and Thursday at 1:00 in room \#002. All team members are expected to attend all meetings. There may be a need to have an additional meeting day, but very seldom.

Data will be turned in at the beginning of each Tuesday's meetings. We will rotate duties of taking notes at all meetings. These notes will accompany the data that is turned into the central office.

These meetings will cover all team issues, conduct student contract meetings and plan events. Please plan on approximately one hour for each meeting. Occasionally, we will have guest speakers and/or administration help us become more of a "team". 


\section{PHONE CALLS AND \\ PARENTAL INVOLVEMENT}

The East High School Freshman Success Academy will repeatedly

attempt to meet and involve each parent. We believe that strong parent

involvement is key to student achievement, appropriate behavior and the

overall success of our students and ultimately our program.

Teachers will be required to reach each parent (not an answering machine) of a designated group of

students every two weeks.

These phone calls and/or home visits will be documented and a component of our data collection process and turned in weekly.

The content of these phone calls will be determined by individual teachers and any team events held. The initial phone call must only contain positive feedback and introductory comments. Please see administration if you need support on negative behavior prior to your first call. Or, hurry and get all calls in prior to any difficulties :)! 


\section{Appendix E}

\section{DATA COLLECTION}

The East High School Freshman Success Academy Teachers will have to collect data for each student each week. Teachers will need to keep accurate attendance records, grade updates, document parent phone calls, track conferences (with students and/or parents), list proficiency areas passed, and record students removed from the learning environment.

This data will need to be reported to the lead teacher at the beginning of Tuesday's team meeting. Data collection will be a necessary component in evaluating our successes as well as our students. We will have a building data coordinator that may also request additional information and assist us interpreting the information.

Data collection is not simply "busy work" but will enable our academy to identify both strengths and weaknesses for continued improvement. 


\section{Appendix F}

\section{Data Collection Sheet}

Meeting Date

Team

A or B

\# of Students on Block Two Roster

\# of Absences in Block Two

Total \# of Phone Calls Made

Total \# of Student Conferences

Total \# of Parent Conferences

Total \# of Resource People Used

Total \# of Present Student Minutes

Outside Learning Environment

\# of Students with Grade of A or B

\# of Students with Grade of F
Teacher

B 


\section{Appendix G}

\section{TICKET INCENTIVE PROGRAM}

The East High School Freshman Success Academy will employ a ticket incentive program. Each teacher will be given tickets weekly that may be given out as deemed necessary. Please give out all tickets weekly.

Students are responsible for writing their name on the ticket and placing it in the can in Ms Heideman's room \#2 (for team A) and Ms. Luaces's room \#29 (for team B). Team members will draw weekly winners at team meetings.

Winners will be announced in classes and allowed to choose one item from the prize drawer. Teachers will be responsible for helping their respective teams stock the prize drawer with various items. 


\section{Appendix $\mathrm{H}$}

\section{$\underline{\text { ASSEMBLIES }}$}

The East High School Freshman Success Academy is committed to honoring students and acknowledging accomplishments and marked improvement (no matter how small it may be (-)). Each nine weeks, teachers will nominate students in the following areas:

$110 \%$ effort

Most improved

Perfect attendance

Scholar (this is done with GPA)

Outstanding student (not just GPA)

Each nomination will be called to the stage and receive a certificate and a small award. This usually consists of a free food coupon. Each category will also have a winner that will receive a certificate, their name displayed in a plaque, a star student tshirt and a prize. The prizes will hopefully be donated and can range from a backpack to a CD walkman.

Teachers will need to nominate and vote on each category. Teachers also will help complete certificates and participate in each assembly. The $2^{\text {nd }}$ and $4^{\text {th }}$ assemblies will also include students being rewarded for each individual area they pass on proficiency.

These assemblies not only honor students and raise selfesteem, they teach appropriate behavior and connect with parents in a positive manner. Hopefully, we can feature a guest feature at each assembly also.

Teachers will need to help request donated items for each assembly to defer costs. Parents will also be notified about each assembly. 


\title{
Appendix I
}

\section{Follow Me To Honor Roll Certificate}

\section{Follow Me To Honor Roll}

HONOR ROLL STUDENT:

I WOULD LIKE TO SPONSOR A FELLOW FRESHMAN

STUDENT TO JOIN ME ON THE HONOR ROLL FOR THE SECOND GRADING PERIOD.

SPONSORED STUDENT:

INITIALS OF ACCEPTANCE:

I WILL REMAIN ON THE HONOR ROLL AND WILL PULL A CLASSMATE ON WITH ME.

\author{
Follow Me To Honor Roll \\ HONOR ROLL STUDENT: \\ I WOULD LIKE TO SPONSOR A FELLOW FRESHMAN \\ STUDENT TO JOIN ME ON THE HONOR ROLL FOR THE SECOND GRADING PERIOD. \\ SPONSORED STUDENT: \\ INITIALS OF ACCEPTANCE: \\ I WILL REMAIN ON THE HONOR ROLL AND WILL PULL A CLASSMATE ON WITH ME.
}




\section{$\underline{\text { Appendix J }}$}

\section{Phone Log Sheet}

Freshman Success Academy Phone Log

Student Name

Team A or B

Phone \#

Alternate \#

Contact Person

Best Time to Call

Sections of the Proficiency Passed (check all that apply): W_R_M_C_S _

Teacher:

Date:

Person spoken to:

Topics discussed:

\begin{tabular}{|l|l|l|l|}
\hline & & & \\
\hline & & & \\
\hline & & & \\
\hline & & & \\
\hline & & & \\
\hline & & & \\
\hline & & & \\
\hline & & & \\
\hline & & & \\
\hline & & & \\
\hline
\end{tabular}




\section{Appendix K}

\section{Freshman Academy Student Success Contract}

Student's Name:

Date: Scheduled Review Date:

Student's Strengths: 1)

2)

Signatures:

\begin{tabular}{|l|l|l|l|}
\hline \multicolumn{1}{|c|}{ Student Goal } & Steps to meet goal & Responsible Party & Progress at Review \\
\hline \multirow{2}{*}{ A. } & 1 & & \\
\cline { 2 - 4 } & 2 & & \\
\cline { 2 - 4 } & 3 & & \\
\cline { 2 - 4 } & 4 & & \\
\hline \multirow{3}{*}{ B. } & 1 & & \\
\hline & 2 & & \\
\cline { 2 - 5 } & 3 & & \\
\cline { 2 - 5 } & 4 & & \\
\hline C. & 1 & & \\
\cline { 2 - 5 } & 2 & & \\
\cline { 2 - 5 } & 3 & & \\
\cline { 2 - 5 } & 4 & & \\
\hline
\end{tabular}




\section{Appendix L}

\section{Teacher Questionnaire}

Thank you for sharing your time with me. I am in my final phase of writing my graduate thesis on the topic of the achievement gap between African-American and White students. My study has centered on the academy reform model and how it affects the achievement gap. Use the back of the questionnaire if needed. Please return the completed form to me. Names are optional.

1. About how long have you been teaching? years teaching in an academy structure years teaching in a non-academy structure total years teaching

2. What are the positive aspects, if any, of teaching in an academy?

3. What are the negative aspects, if any, of teaching in an academy?

4. How does the academy structure affect student attendance and achievement?

5. What advice do you have for other teachers working in an academy structure?

6. What conclusions have you drawn in regards to the academy structure at East High School? 


\title{
$\underline{\text { Appendix M }}$
}

\author{
School Administrator Questionnaire
}

Thank you for sharing your valuable time with me. I am in my final phase of writing my graduate thesis on the topic of the achievement gap between African-American and White students. My study has centered on the academy reform model and how it affects the achievement gap. Use the back of the questionnaire if needed. Please return the completed form to me. Names are optional.

1. About how long have you been a school administrator? years administrating in an academy school years administrating in a non-academy school total years as an administrator

2. What are the critical components that need to be in place within a school in order for the academy structure to be successful?

3. What are the positive aspects, if any, of the academy structure in a school?

4. What are the negative aspects, if any, of the academy structure in a school?

5. In your experience, how does the academy structure affect the attendance and achievement of the students?

6. What are your concluding thoughts with regard to the academy school structure? 


\section{$\underline{\text { Appendix N }}$}

\section{Parent Questionnaire}

Thank you for taking the time to complete this questionnaire. I am in the final stage of writing my graduate thesis examining the effectiveness of the academy structure in reducing the achievement gap between African-American and White students. Please return this form to me. This form is referring to your child's freshman year at East High School.

Name:

Child's Name:

Date:

Please circle the reply that best describes your experience last year:

1. Did you feel as if you were regularly contacted regarding your child's progress?
a. I strongly agree
b. I agree
c. I disagree
d. Undecided

2. Did you feel more involved in your child's education?
a. I strongly agree
b. I agree
c. I disagree
d. Undecided

3. Did you think that your child's academic achievement improved in the Freshman Success Academy?
a. I strongly agree
b. I agree
c. I disagree
d. Undecided

4. Do you have any comments regarding your child's experience in the Freshman Success Academy? 


\section{$\underline{\text { Appendix } \mathbf{O}}$}

\section{Student Questionnaire}

Thank you for taking the time to fill out this questionnaire. This is to help me to finish writing a thesis on the Freshman Success Academy. Please return this form to me. Use the back of the form if you need more space.

Name:

Date:

1. Describe what things you liked, if any, about the Freshman Success Academy?

2. Describe what things you did not like, if any, about the Freshman Success Academy?

3. Do you feel that the Freshman Success Academy prepared you to be successful in high school? Explain.

4. What would you change, if anything, about the Freshman Success academy? 


\section{References:}

Alson, A. (2003). The Minority Student Achievement Network. Educational Leadership, pp. 76-78.

Baranchik, A., \& Cherkas, B. (2002). Identifying gaps in mathematics preparation that contribute to ethnic, gender, and American/foreign differences in precalculus performance. Journal of Negro Education, 71, pp. 253-267.

Borja, R. (2002). ‘Achievement Gap’ is International Problem, UNICEF Analysis Says. Education Week, 22, p. 10.

Borman, G. (2003). How can Title 1 improve achievement? Educational Leadership, pp. 49-53.

Cheng, S., \& Starks, B. (2002). Radical differences in the effects of significant others on students’ educational expectations. Sociology of Education, 75, pp. 306-327.

Codding, J., Tucker, M. (2000). A new high school design focused on performance: part 1. NASSP Bulletin, pp. 79-92.

Corbett, D., Wilson, B. (2002). What urban students say about good teaching. Educational Leadership, pp. 18-22.

Darling-Hammond, L. (1997). The Right to Learn. San Francisco: Jossey-Bass.

Elliott, M., Lawrence, M., \& Gilroy, C. (2002). Career Academies: Additional Evidence of Positive Student Outcomes. Journal of Education for Students Placed at Risk, 7(1), pp 71-90.

Gehring, J. (2002). Ohio Faces up to New Achievement Data. Education Week, pp. 2023.

Gilroy, M. (2002). Waking up students' math/science attitudes and achievement. The 
Education Digest, pp. 39-44.

Hammersley, M. (2001). Interpreting Achievement Gaps: Some Comments on a

Dispute. British Journal of Educational Studies, 3, 285-298.

Hanser, L., \& Robyn, A. (2000). Implementing High School JROTCCAreer Academies ((MR-741-OSD). Santa Monica, CA: RAND.

Haycock, K. (2001). Closing the Achievement Gap. Educational Leadership, pp. 6-11.

Heimel, C. (2003). Teacher Quality Said Key in Closing Achievement Gap. Reading Today, p. 18.

Hrabowski, F. (2003). Raising minority achievement in science and math. Educational Leadership, pp. 44-48.

Jerald, C., \& Ingersoll, R. (2002). All Talk, No Action: Putting an End to Out-of Field Teaching. Retrieved July 19, 2003, from http://www.edtrust.org.

Jordan, W., McPartland, J., Legters, N., \& Balfanz, R. (2000). Creating a Comprehensive School Reform Model: the Talent Development High School with Career Academies. Journal of Education for Students Placed at Risk, 5(1\&2), pp. 159-181.

Kober, N. (2001). It Takes More Than Testing: Closing the Achievement Gap. Washington, D.C.: Center on Education Policy.

Lee, J. (2002). Racial and ethnic achievement gap trends: reversing the progress toward equity? Educational Researcher, 31, pp. 3-12.

Lee, V., \& Smith, J. (1995). Effects of High School Restructuring and Size on Gains in Achievement and Engagement for Early Secondary School Students. Sociology Of Education, 68, pp. 241-270. 
Lubienski, S. (2002). A closer look at Black-White mathematics gaps: intersections of race and SES in NAEP achievement and instructional practices data. Journal of Negro Education, 71, pp. 269-287.

Lucas, S. (1999). Tracking Inequality: Satisfaction and Mobility in American High Schools. New York: Teachers College Press.

McCombs, B. (2000). Reducing the achievement gap. Society, pp. 29-36.

Nettles, M., Millett, C., \& Ready, D. (2003). Attacking the African American - White Achievement Gap on College Admissions Tests. Brookings Papers on Education Policy, pp. 215-252.

Quindlen, T. (2002). Reaching minority students: strategies for closing the achievement gap. Education Update, pp. 5-8.

Roach, R. (2001). SAT Minority Achievement Gap Persists. Black Issues in Higher Education, p. 12.

Rutherford, M. (1998, October). How to Make a Better Student. Time Magazine, pp. 78-86.

Schreiber, J., \& Chambers, E. (2002). After-school pursuits, ethnicity, and achievement for $8^{\text {th }}$ - and $10^{\text {th }}$ - grade students. The Journal of Educational Research, 96, pp. $90-100$.

Shorr, A., \& Hon, J. (1999). They Said It Couldn’t Be Done: Implementing a Career Academy Program for a Diverse High School Population. Journal of Education for Students Placed at Risk, 4(4), pp. 379-391.

Slavin, R. (2001). Putting the School Back in School Reform. Educational Leadership, pp. 22-27. 
Spencer, M.B., Noll, E., Stoltzfus, J., \& Harpalani, V. (2001). Identity and school adjustment: revisiting the "acting white” assumption. Educational Psychologist, 36, pp. 21-30.

Stern, D., Raby, M., \& Dayton, C. (1992). Career Academies: Partnerships for Restructuring American High Schools. San Francisco: Jossey-Bass.

Taylor, K. (2003). Through the Eyes of the Students: African American Students Offer Personal Insights into Reasons for the Minority Achievement Gap. Educational Leadership, pp. 72-75.

The Education Trust. (winter, 2002-2003). Education Watch - Ohio - Key Education Facts and Figures. Retrieved July 19, 2003, from http://www.edtrust.org. 


\section{VITA}

Eric William Reini grew up in a few different locations as a child, but spent most of his time in Lewiston, NY. His family moved to Toledo, Oh when he was in high school. His parents are George and Janet Reini. He is the oldest of five children. His sister, Noelle is married with two children and is an administrator of a daycare in Columbus Grove, OH. His brother, Seth, is currently working on his PhD in Research Biology at the University of Florida in Gainesville, FL. His other two sisters, Megan and Bethany, are in the $12^{\text {th }}$ and the $8^{\text {th }}$ grade respectively.

Eric came to know the Lord as her personal Savior at the age of six. His relationship with Christ and the church have been important priorities throughout his life. Today, he is actively involved in Delaware Bible Church where he serves as a Home Church leader and is involved in children's ministries.

Eric graduated from Emmanuel Baptist High School in Toledo, OH in 1991. He attended Cedarville University and majored in Mathematics Secondary Education. He played soccer for four years at Cedarville. It was his senior year that he met his wife, Diana. He graduated in 1995, and a year later they were married.

After graduation, Eric took a job teaching math and coaching soccer at Delaware Christian School. In addition to teaching, he took on administrative responsibilities including at various times athletic director, chapel coordinator, and guidance counselor. 
After six years at Delaware Christian, Eric switched over to the public school arena where he accepted a job as math teacher at East High School in Columbus, OH. He is in his third year at East.

Eric and Diana have two daughters, Petra Grace - age 3 and Katriella Joy - age 1. Diana stays at home caring for the daughters and the home. 